\title{
Plankton development and trophic transfer in seawater enclosures with nutrients and Phaeocystis pouchetii added
}

\author{
J. C. Nejstgaard ${ }^{1,{ }^{*}}$, M. E. Frischer ${ }^{2}$, P. G. Verity ${ }^{2}$, J. T. Anderson ${ }^{2,3}$, A. Jacobsen ${ }^{1}$, \\ M. J. Zirbel ${ }^{4}$, A. Larsen' ${ }^{1}$ J. Martínez-Martínez ${ }^{1,5,12}$, A. F. Sazhin ${ }^{6}$, T. Walters ${ }^{2}$, \\ D. A. Bronk ${ }^{7}$, S. J. Whipple ${ }^{8}$, S. R. Borrett ${ }^{8,9}$, B. C. Patten ${ }^{8}$, J. D. Long ${ }^{10,11}$ \\ ${ }^{1}$ UNIFOB, Department of Biology, University of Bergen, PO Box 7800, 5020 Bergen, Norway \\ ${ }^{2}$ Skidaway Institute of Oceanography, 10 Ocean Science Circle, Savannah, Georgia 31411, USA \\ ${ }^{3}$ Morgan State University, Estuarine Research Center, St. Leonard, Maryland 20685-2433, USA \\ ${ }^{4}$ COAS, Oregon State University, Corvallis, Oregon 97331-5503, USA \\ ${ }^{5}$ Plymouth Marine Laboratory, Prospect Place, The Hoe, Plymouth PL1 3DH, UK \\ ${ }^{6}$ P. P. Shirshov Institute of Oceanology RAS, 36 Nakhimovsky Prospect, Moscow 117851, Russia \\ ${ }^{7}$ Virginia Institute of Marine Sciences, Gloucester Point, Virginia 23062, USA \\ ${ }^{8}$ Institute of Ecology, University of Georgia, Athens, Georgia 30602, USA \\ ${ }^{9}$ Computational Learning Laboratory, CSLI, Stanford University, Stanford, California 94305, USA \\ ${ }^{10}$ Department of Biology, Georgia Institute of Technology, Atlanta, Georgia 30332-0230, USA \\ ${ }^{11}$ Northeastern University Marine Science Center, 430 Nahant Road, Nahant, Maryland 01908, USA \\ ${ }^{12}$ Present address: Department of Biological Oceanography, NIOZ, PO Box 59, 1790 AB Den Burg, Texel, The Netherlands
}

\begin{abstract}
In high latitude planktonic ecosystems where the prymnesiophyte alga Phaeocystis pouchetii is often the dominant primary producer, its importance in structuring planktonic food webs is well known. In this study we investigated how the base of the planktonic food web responds to a $P$. pouchetii colony bloom in controlled mesocosm systems with natural water enclosed in situ in a West Norwegian fjord. Similar large $\left(11 \mathrm{~m}^{3}\right)$ mesocosm studies were conducted in 2 successive years and the dynamics of various components of the planktonic food web from viruses to mesozooplankton investigated. In 2002 (4 to 24 March), 3 mesocosms comprising a control containing only fjord water; another with added nitrate (N) and phosphate (P) in Redfield ratios; and a third with added N, P, and cultured solitary cells of $P$. pouchetii, were monitored through a spring bloom cycle. In 2003 (27 February to 2 April) a similar set of mesocosms were established, but cultured P. pouchetii was not added. As expected, during both years, addition of $\mathrm{N}$ and $\mathrm{P}$ without addition of silicate resulted in an initial small diatom bloom followed by a colonial bloom of $P$. pouchetii (600 to $800 \mu \mathrm{g} \mathrm{C} \mathrm{l}^{-1}$ ). However, the hypothesis that addition of solitary cells of $P$. pouchetii would enhance subsequent colony blooms was not supported. Interestingly, despite the large production of Phaeocystis colonial material, little if any was transferred to the grazing food web, as evidenced by non-significant effects on the biomass of micro- and mesozooplankton in fertilized mesocoms. Separate experiments utilizing material from the mesocosms showed that colonies formed from solitary cells at rates that required only ca. $1 \%$ conversion efficiencies. The results are discussed from the perspective of future research still required to understand the impact of life cycle changes of this enigmatic phytoplankter on surrounding ecosystems.
\end{abstract}

KEY WORDS: Phaeocystis pouchetii $\cdot$ Mesocosms $\cdot$ Nutrients $\cdot$ Fjord $\cdot$ Biocomplexity

Resale or republication not permitted without written consent of the publisher

\section{INTRODUCTION}

The phytoplankton genus Phaeocystis is a cosmopolitan group that typically produces prodigious blooms of gelatinous colonies in high latitude marine environments. A particularly salient aspect of this genus is its ability to change between the well-known colonial stage and the less studied motile solitary stage. Colonies may be $\mathrm{mm}$ to $\mathrm{cm}$ in diameter and contain more than hundreds of cells in the periphery of a 
gelatinous polysaccharide 'skin' (Chen et al. 2002). Solitary cells may be either motile or non-motile, and are typically 3 to $9 \mu \mathrm{m}$ in diameter (Rousseau et al. 1994). This unusually large range of sizes between colonies and solitary cells (ca. 6 to 11 orders of magnitude in biovolume) can significantly alter material flow among trophic levels and export from the upper ocean (Wassmann et al. 1990, Lancelot et al. 1998). Furthermore, each stage is thought to function in different ways in order to reduce losses to either small or large zooplankton and viruses, and thus Phaeocystis spp. effectively function as dual species (Weisse et al. 1994, Smaal \& Twisk 1997, Hamm et al. 1999, Jacobsen 2000, Verity 2000, Jakobsen \& Tang 2002, Tang 2003).

The dual life history of colonial and solitary cell stages was described over 50 yr ago (Kornmann 1955), and the dominant morphology appears to alter the ecosystem function from a regenerative system (solitary cells) to one associated with the classical fisheries food chain (colonies, Fernandez et al. 1992). Transitions between colonial and solitary cell stages are probably under ecological control, but the mechanisms and ecological benefits are poorly known. Several investigators have proposed that such a life cycle is a form of 'bet-hedging', whereby one morphotype confers protection against predation or viral attack while the other enables higher growth efficiency. However, this is currently under debate (e.g. review by Schoemann et al. 2005, Nejstgaard et al. (2006). Interestingly, in at least 1 species, Phaeocystis globosa, a complex sexual life cycle involving haploid and diploid solitary and diploid colonial cells has been observed (Valero et al. 1992, Rousseau et al. 1994, Peperzak et al. 2000), but this transition has not been reported in all Phaeocystis species, including P. pouchetii (Jacobsen 2002). In our laboratory we have observed differential gene expression in $P$. globosa between solitary cells and colonies, but most of the detected genes have not been identified (Frischer unpubl. data).

The environmental stimuli that trigger transitions between solitary and colonial life stages are also poorly understood. Some investigators have reported that the transformation from solitary cells to colonies of Phaeocystis globosa can be induced by chemical cues from grazers (Jakobsen \& Tang 2002, Long 2005), as well as various environmental stimuli including light, nutrients and the presence of diatoms as attachment sites (Boalch 1987, Verity et al. 1988b, Rousseau et al. 1994, Escaravage et al. 1995, Peperzak et al. 1998). However, to our knowledge there are no reports in the literature of the induction of $P$. pouchetii single cells to colonies under laboratory conditions.

Phaeocystis spp. blooms generally occur seasonally either prior to, during, or immediately following a bloom of diatoms. However, the absolute and relative abundance of Phaeocystis spp. colonies during blooms varies among locations and among years at a given location. In some cases, Phaeocystis spp. may be a minor component or may develop almost monospecific blooms (Lancelot et al. 1998). Even the solitary cell stage can dominate (Wassmann et al. 2005). While silicate availability can be a strong predictor of diatom occurence (see Egge \& Aksnes 1992), silicate availability is often not a predictor of whether Phaeocystis spp. will occur (Verity et al. 1988a, Wassmann et al. 2000, Reigstad et al. 2002, Larsen et al. 2004), nor do diatoms or Phaeocystis spp., in either life cycle stage have clear physiological advantages over the other, although colonies may be preferred when nitrogen is present as nitrate, whereas solitary cells better assimilate ammonium (Riegman \& van Boekel 1996, Hamm et al. 1999).

Thus, there remains a considerable amount of debate concerning the quantitative response of high latitude planktonic communities to colonial blooms of Phaeocystis spp. and what, if any, adaptive advantage is provided to Phaeocystis spp. by colony formation (Verity \& Medlin 2003). Since colony formation may defend the algae against predation, bacterial and viral attacks, we hypothesize that its results in trophic sequestration of nutrients and energy into forms not easily accessible to planktonic grazing and regenerating communities. In this study we describe experimental manipulations in $11 \mathrm{~m}^{3}$ mesocosms of natural plankton communities in a west Norwegian fjord designed to stimulate colonial blooms of $P$. pouchetii to test this hypothesis and to quantify the response of the planktonic community (from viruses to mesozooplankton) to such a bloom.

\section{MATERIALS AND METHODS}

Mesocosm initiation. We conducted 2 sets of experiments, each consisting of 3 transparent polyethylene enclosures ( $4.5 \mathrm{~m}$ deep, $2 \mathrm{~m}$ diameter, ca. $11 \mathrm{~m}^{3}, 90 \%$ transmission of photosynthetically available radiation, PAR, made by ANI-TEX, Notodden). The experiments were conducted in the Raunefjord at the Norwegian National Mesocosm Center located at the Marine Biological field station of the University of Bergen in western Norway $\left(60^{\circ} 16^{\prime} \mathrm{N}, 05^{\circ} 14^{\prime} \mathrm{E}\right)$. The design of the mesocosms is illustrated in Fig. 1. Studies were conducted between 4 March and 24 March 2002 and 27 February and 2 April 2003. Additional details of the location and the mesocosm facility can be found at http://www.bio.uib.no/lsf/inst2.html.

The mesocosms were filled in situ $1 \mathrm{~d}$ prior to the initiation of each experiment by pumping unfiltered fjord water from $5 \mathrm{~m}$ depth using a large submersible 
centrifugal pump, specially designed to minimally damage live plankton, with a flow rate of ca. $1.5 \mathrm{~m}^{3}$ min $^{-1}$ (ITT Flycht A/S, Model 3085-182). To ensure that each mesocosm was as similar as possible, the individual mesocosms were filled sequentially, a third at a time, such that the process was staggered. All mesocosms were filled within $1 \mathrm{~h}$. The mesocosms were well mixed by an airlift system that recirculated the entire volume ca. 5 times $\mathrm{d}^{-1}$ (ca. $401 \mathrm{~min}^{-1}$ ) for the duration of each experiment (Jacobsen et al. 1995). To allow introduction of new species, avoid substantial $\mathrm{pH}$ changes, and replace sampled water over the course of the experiment, $10 \%$ of the water in each mesocosm was renewed daily with fjord water (ca. $2.5 \mathrm{~m}$ ) using small submersible aquarium pumps (Fig. 1). During the 2002 experiment, water renewal was maintained from 4 to 18 March and during the 2003 experiment from 27 February to 20 March. For additional discussion concerning the importance of water renewal see Egge (1993) and Williams \& Egge (1998).

Treatments. During the 2 experiments, each with 3 mesocosms, 2 mesocosms were amended with nitrate $\left(\mathrm{NaNO}_{3}\right)$ and phosphate $\left(\mathrm{KH}_{2} \mathrm{PO}_{4}\right)$ (' $\left.\mathrm{NP}^{\prime}\right)$ corresponding to an initial enrichment of $16 \mu \mathrm{M}$ nitrate and $1 \mu \mathrm{M}$ phosphate by the addition of $100 \mathrm{ml}$ each of stock solutions of $\mathrm{NaNO}_{3}(1.76 \mathrm{M})$ and $\mathrm{KH}_{2} \mathrm{PO}_{4}(0.11 \mathrm{M})$. Nutrients removed by the $10 \%$ water renewal were replaced daily by the addition of $10 \mathrm{ml}$ each of the

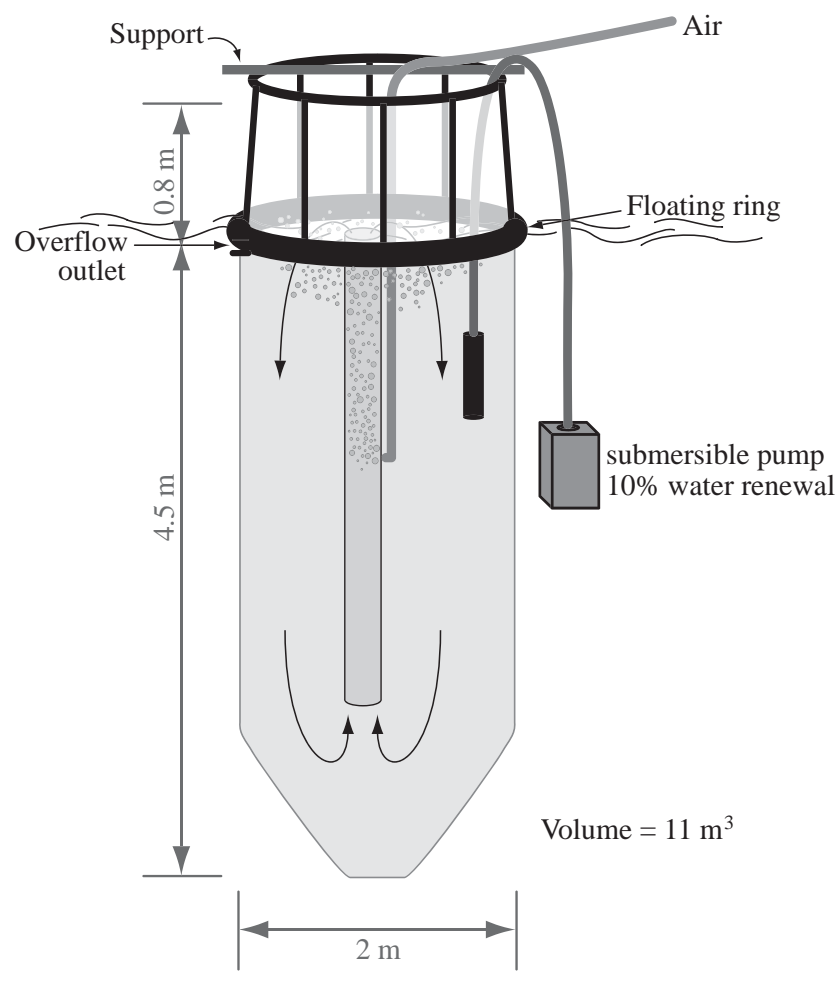

Fig. 1. Mesocosm design used in this study nutrient stock solutions equivalent to daily additions of 0.1 and $1.6 \mu \mathrm{M}$, respectively. In the 2002 experiment, based on the low nutrient concentrations measured on March 12, both nutrient enriched mesocosms were augmented with additional nutrients corresponding to $8 \mu \mathrm{M}$ nitrate and $0.5 \mu \mathrm{M}$ phosphate during the evening of 12 March. The third mesocosm in each experiment was left unamended and served as a control treatment. During the 2002 experiment, $40 \mathrm{l}$ of a late exponential growth stage $\left(8.25 \times 10^{4}\right.$ cells ml $\left.{ }^{-1}\right)$ culture of Phaeocystis pouchetii solitary cells were added to 1 of the nutrient amended mesocosms ('NPF') corresponding to an initial addition of ca. 300 cells $\mathrm{ml}^{-1}$, in order to investigate if higher initial abundance of flagellated cells would induce more or earlier colony formation. The culture of $P$. pouchetii was originally isolated from Raunefjorden in 2001 and grown in f/2-Si media (Guillard 1975).

Sampling procedures and analyses. Salinity and temperature profiles in each mesocosm were determined using a SD204 CTD (SAIV). Surface irradiance (PAR) was recorded continuously with a LI-COR 190 quantum sensor (LI-COR) mounted horizontally ca. $4 \mathrm{~m}$ above the sea surface. Irradiance was averaged every $15 \mathrm{~min}$ and stored using a LI-COR 1400 data logger. In situ light profiles from surface to the bottom of the mesocosms were occasionally obtained using a horizontally mounted LI-192 underwater quantum sensor. Surface water samples for analysis of nutrient concentration, viral and bacterial abundance, chlorophyll a (chl a), phytoplankton and microzooplankton were collected in $30 \mathrm{l}$ carboys $12 \mathrm{~h}$ after initiation of the experiment and approximately every third day at 08:00 $\mathrm{h}$ afterward until the termination of the experiments. Because the mesocosms were fully mixed, it was not necessary to analyze depth-profiled samples for these parameters. Chl a was determined in triplicate water samples (20 to $100 \mathrm{ml}$ ) according to Parsons et al. (1984). Water was filtered onto $25 \mathrm{~mm} 0.45 \mu \mathrm{m}$ cellulose-acetate filters (Sartorius), immediately extracted in $90 \%$ acetone overnight at $4^{\circ} \mathrm{C}$, and analyzed using a Turner Designs 10-AU fluorometer. Concentrations of ammonium, phosphate, and silicate were determined on fresh samples at each sampling event. Ammonium concentrations were determined fluorometrically using a Turner Designs 10-AU fluorometer as described by Holms et al. (1999). Phosphate and silicate concentrations were determined colorimetrically as described by Valderrama (1995) using a Shimadzu UV-160 spectrophotometer. Nitrate concentrations were determined as described by Hagebø \& Rey (1984) on chloroform fixed samples (1\% vol:vol) using a nutrient autoanalyzer (Skalar). Chloroform fixed samples were stored at $4^{\circ} \mathrm{C}$ and analyzed within 1 mo of collection. 
To enumerate phytoplankton and microzooplankton $>10 \mu \mathrm{m}$, EDTA (10 mM final concentration) was added to $60 \mathrm{ml}$ of whole water samples, mixed gently by inversion, fixed with HPLC grade glutaraldehyde $(0.5 \%$ final concentration), and stored at $4{ }^{\circ} \mathrm{C}$. In trial experiments, 10 mM EDTA effectively dispersed Phaeocystis pouchetii colonies without seemingly affecting cell morphology or total cell abundance (data not shown).

Phytoplankton and microzooplankton $<10 \mu \mathrm{m}$ were identified and enumerated by epifluoresence microscopy. Unfiltered freshwater samples $(60 \mathrm{ml})$ were gently passed through a $10 \mu \mathrm{m}$ nylon mesh and fixed with HPLC grade glutaraldehyde (0.5\% final concentration) and stored at $4^{\circ} \mathrm{C}$. Each sample was stained with proflavin (100 $\mathrm{ng} \mathrm{ml^{-1 }}$ final concentration stock = $5.5 \mu \mathrm{g} \mathrm{ml}^{-1}$ ) and DAPI (25 $\mathrm{ng} \mathrm{ml}^{-1}$ final concentration stock $=500 \mathrm{ng} \mathrm{ml}^{-1}$ ) as described by Porter \& Feig (1980) and Haas (1982), except that higher concentrations of stain were required to effectively stain Phaeocystis pouchetii cells. We made 3 epifluorescent slides by gently filtering $15 \mathrm{ml}$ of the fixed and stained samples onto black $0.2 \mu \mathrm{m}$ (25 mm diameter) polycarbonate filters using a hand-pump with $<0.5 \mathrm{~mm} \mathrm{Hg}$ vacuum pressure. Filters were mounted onto glass slides with a cover slip and stored at $-20^{\circ} \mathrm{C}$ until analysis. Cells were visualized by epifluoresence microscopy using an Olympus BX-60 fluorescence microscope equipped with a $60 \times$ Planapo NA 1.40 oil objective. For each slide, a minimum of 20 fields or 300 cells were examined either manually or using a semi-automated custom image analysis system 'Skipper' (www.skipperimaging.com) after digitally capturing images using a Retiga 1300 Cooled Color 12-bit digital camera (image resolution $1200 \times 1024$ pixels).

Flagellated Phaeocystis pouchetii solitary cells and other phytoplankton and microzooplankton were identified based on their fluorescence, shape and size, and were enumerated in water samples that passed through the $10 \mu \mathrm{m}$ nylon mesh. Microflagellates (autotrophic, heterotrophic, and mixotrophic flagellates), diatoms, and total $P$. pouchetii cells (solitary and colonial) were identified and enumerated from the EDTA treated samples. Ciliates and large dinoflagellates (<50 $\mu \mathrm{m}$ diameter) were enumerated in the EDTA treated samples by screening and counting all cells present on the whole slide (15 ml sample). In 2003, cell volumes were calculated by approximation of simple geometrical 3D shapes and converted into cell carbon as described in Menden-Deuer \& Lessard (2000).

The concentration and size of Phaeocystis pouchetii colonies were determined within hours of water collection. Water samples (50 to $100 \mathrm{ml}$ ) were gently concentrated 5 to 10 fold by reverse filtration though a $10 \mu \mathrm{m}$ mesh. The entire concentrated sample was placed into $3 \mathrm{ml}$ well plates ( $3 \mathrm{ml}$ per well) and allowed to settle for
$1 \mathrm{~h}$ at $4^{\circ} \mathrm{C}$. Colony concentrations and size were determined by averaging counts from at least 4 wells using a Nikon Diaphot inverted microscope equipped with a $40 \times$ objective. All sample processing was conducted at in situ temperature $\left(5^{\circ} \mathrm{C}\right)$.

Mesozooplankton were sampled at the start of each experiment by filtering $4 \mathrm{~m}^{3}$ of water though a $90 \mu \mathrm{m}$ WP plankton net in triplicate before, between, and after filling of the meoscosms, and at the end of the experiment by emptying each mesocosm through the same net. In addition to sampling at the start and end of each experiment, during each experiment mesozooplankton were sampled periodically by net hauls $(30 \mathrm{~cm}$ diameter, $90 \mu \mathrm{m}$ mesh) from the bottom to the surface of the mesocosms. During the first experiment (2002), mesocosms were sampled on 9, 15, and 24 March; during the second experiment (2003), mesozooplankton were sampled on 24 March. Mesozooplankton were fixed immediately in $4 \%$ buffered formaldehyde and identified, enumerated and sized using a Wild M10 dissecting microscope. Mesozooplankton abundance was converted into carbon biomass by applying accepted size-specific carbon conversion factors (Conover \& Lalli 1972, Theilacker \& Kimball 1984, Båmstedt 1986, Daan 1986, Whyte et al. 1987, Blom et al. 1989, Båmstedt et al. 1990, Falkenhaug 1991, Widdows 1991, Karlson \& Båmstedt 1994, Gorsky \& Fenaux 1998).

Bacterial abundance was determined in each mesocosm ca. every third day during each experiment. Total cell abundance was determined by direct counting of DAPI stained cells in combination with the estimation of the physiological status of individual cells using the VSP (vital stain probe) technique as described by Howard-Jones et al. (2001). Upon collection, whole water samples $(15 \mathrm{ml})$ were equilibrated in sterile glycerol ( $25 \%$ final concentration) and stored at $-20^{\circ} \mathrm{C}$. Sample analysis was completed within 3 mo of sample collection. Cells were visualized using an Olympus BX 60 fluorescence microscope equipped with a $100 \times$ UPLANFL NA 1.35 oil objective. Enumeration was facilitated using 'Skipper' after capturing digital micrographs using a Photonic Science Color Cool View cooled, 3-chip, color integrating charged-coupled device camera system (image resolution $768 \times 576$ pixels or $640 \times 480$ pixels), as previously described by Williams et al. (1998).

Total viral abundance was estimated by flow cytometry (FCM) as previously described (Marie et al. 1999a,b). All FCM analyses were performed using a FACSCalibur Flow Cytometer (Becton Dickinson) equipped with an air-cooled laser providing $15 \mathrm{~mW}$ at $488 \mathrm{~nm}$ using a standard filter set. Water samples were fixed with EM grade glutaraldehyde $(0.5 \%$ final concentration) for $30 \mathrm{~min}$ at $4^{\circ} \mathrm{C}$, flash frozen in liquid nitrogen, and stored at $-70^{\circ} \mathrm{C}$ until analysis. Prior to counting, samples were thawed, diluted 10- to 200-fold 
in sterile filtered $(0.02 \mu \mathrm{m})$ TE buffer (Tris $10 \mathrm{mM}$, EDTA $1 \mathrm{mM}, \mathrm{pH}$ 8), and stained for $10 \mathrm{~min}$ at $80^{\circ} \mathrm{C}$ in the dark with SYBR Green I solution $(5 \mu \mathrm{l}$ per $500 \mu \mathrm{l}$ sample; Molecular Probes). Fluorescent microspheres (Molecular Probes) with a diameter of $0.95 \mu \mathrm{m}$ were added to all samples as an internal counting standard. The discriminator was set on green fluorescence and the samples were analyzed for 1 min at a count event rate between 100 and $1000 \mathrm{~s}^{-1}$.

Colony formation rates. During the first mesocosm experiment (2002), colony formation rates were estimated. Water from the NPF mesocosm was gravityfiltered through $47 \mathrm{~mm} 8 \mu \mathrm{m}$ pore size polycarbonate filters in order to remove all Phaeocystis pouchetii colonies present in the water while allowing $P$. pouchetii solitary cells to pass. Aliquots of $2.5 \mathrm{ml}$ of colony-free water were gently pipetted into each of 24 wells in sterile acid-cleaned well plates (Nalge Nunc International). In order to test the hypothesis that surfaces for settlement stimulate colony formation (e.g. Rosseau et al. 1994), half of the wells received $50 \mu$ of a $1 \mathrm{mg} \mathrm{ml}^{-1}$ solution of diatomaceous earth (Fisher Scientific, equivalent to ca. $10^{2}$ to $10^{3}$ diatomaceous particles $\mathrm{ml}^{-1}$ ). The diatomaceous earth was equilibrated in filtered NPF-mesocosm water for $24 \mathrm{~h}$ prior to the experiment. Well plates were incubated at in situ temperature $\left(5^{\circ} \mathrm{C}\right)$ under dim light with a 14:10 light/dark photoperiod. Light levels during the light and dark periods averaged 62 and $8 \mu \mathrm{mol}$ photons $\mathrm{m}^{-2} \mathrm{~s}^{-1}$, respectively. Light levels were estimated using a handheld QSL 100 light meter (Biospherical Instruments). We initiated 3 sets of experiments beginning on 10, 13 and $16 \mathrm{March}$, respectively, and colonies were counted in each well using a Leica zoom stereomicroscope daily for $6 \mathrm{~d}$. All process manipulation and analysis were conducted at $5^{\circ} \mathrm{C}$ in a walk-in cold room.

Statistical analyses. The statistical packages SAS (v8.0; SAS Institute) and SigmaStat (SPSS, v3.00) were used for all statistical analyses. Net Phaeocystis pouchetii growth rates and production were calculated from liner regressions of log concentrations. Comparisons of absolute cell concentration between and within mesocosms and comparisons of growth rates were conducted by ANOVA and Student's t-tests. Significance was reported for all correlations at the $95 \%$ confidence level $(\mathrm{p}<0.05)$.

\section{RESULTS}

\section{General overview}

The addition of nitrate $(\mathrm{N})$ and phosphate $(\mathrm{P})$ to the mesocosms significantly increased the concentration of these nutrients above those of the unamended control mesocosms (Figs. $2 \& 3$ ) and the outside fjord water (Fig. 4), and resulted in large blooms of Phaeocystis pouchetii colonies (max. 100 to 300 colonies $\mathrm{ml}^{-1} ; 600$ to $800 \mu \mathrm{g} \mathrm{C}^{-1}$ ) in each fertilized mesocosm (Figs. 5d-f, $6 \mathrm{~d}-\mathrm{f}, 7 \mathrm{a}-\mathrm{c})$. However, despite the large production of $P$. pouchetii, little if any of this production was transferred to the grazing food web. The initial addition of cultured $P$. pouchetii solitary cells did not result in early initiation of colony formation or eventual higher concentrations of $P$. pouchetii colonies compared to other fertilized mesocosms, as was initially hypothesized (Fig. 5d-f). Instead, higher diatom, microflagellate and dinoflagellate concentrations occurred in the NPF treatment, possibly suggesting that, unlike native $P$. pouchetii solitary flagellated cells, cultured cells were more susceptible to zooplankton grazing (Figs. $5 g-i$ \& 8). These major trends are described in further detail below.

\section{Irradiance and hydrography}

Irradiance patterns were similar during both experimental studies. In both experimental years the maximum daily irradiance varied from 100 to $1300 \mu \mathrm{mol}$ photons $\mathrm{m}^{-2} \mathrm{~s}^{-1}$ at the surface and from ca. 1 to 4 orders of magnitude lower at the bottom of the mesocosms. During the 2002 experiment there were 16 mostly sunny days and 5 mostly cloudy days, and during the 2003 experimental period there were 19 mostly sunny days and 17 mostly cloudy days. Because both experimental periods bracketed the spring equinox, there were ca. $12 \mathrm{~h}$ of light $\mathrm{d}^{-1}$ in both years. The temperature and salinity of the mesocosms were also similar during both years and changed little during the experimental periods. Temperatures in the mesocosms closely followed those in the surrounding fjord $\left(<0.2^{\circ} \mathrm{C}\right.$ difference) and increased gradually from the start of each experiment to its conclusion. In 2002 water temperatures increased from 4.9 to $5.6^{\circ} \mathrm{C}$ over the course of the study period, and in 2003 from 3.5 to $4.5^{\circ} \mathrm{C}$ over the course of the experiment. During 2002 the salinity in each mesocosm was between 31.0 and 31.7 PSU, and in 2003 between 31.5 and 31.7 PSU in each mesocosm over the duration of the experiment. These temperature and salinity ranges are typical for Bergen-area fjords in March (Erga \& Heimdal 1984). Based on daily depth profiles of temperature, salinity and in situ fluorescence in each mesocosm, there was no evidence of stratification in the mesocosms, indicating that the systems were well mixed.

\section{Nutrients and chlorophyll}

Nutrient ( $\mathrm{N}, \mathrm{P}$, and $\mathrm{Si}$ ) and pigment (chl $a$ and phaeophytin) concentrations in both mesocosms and the 

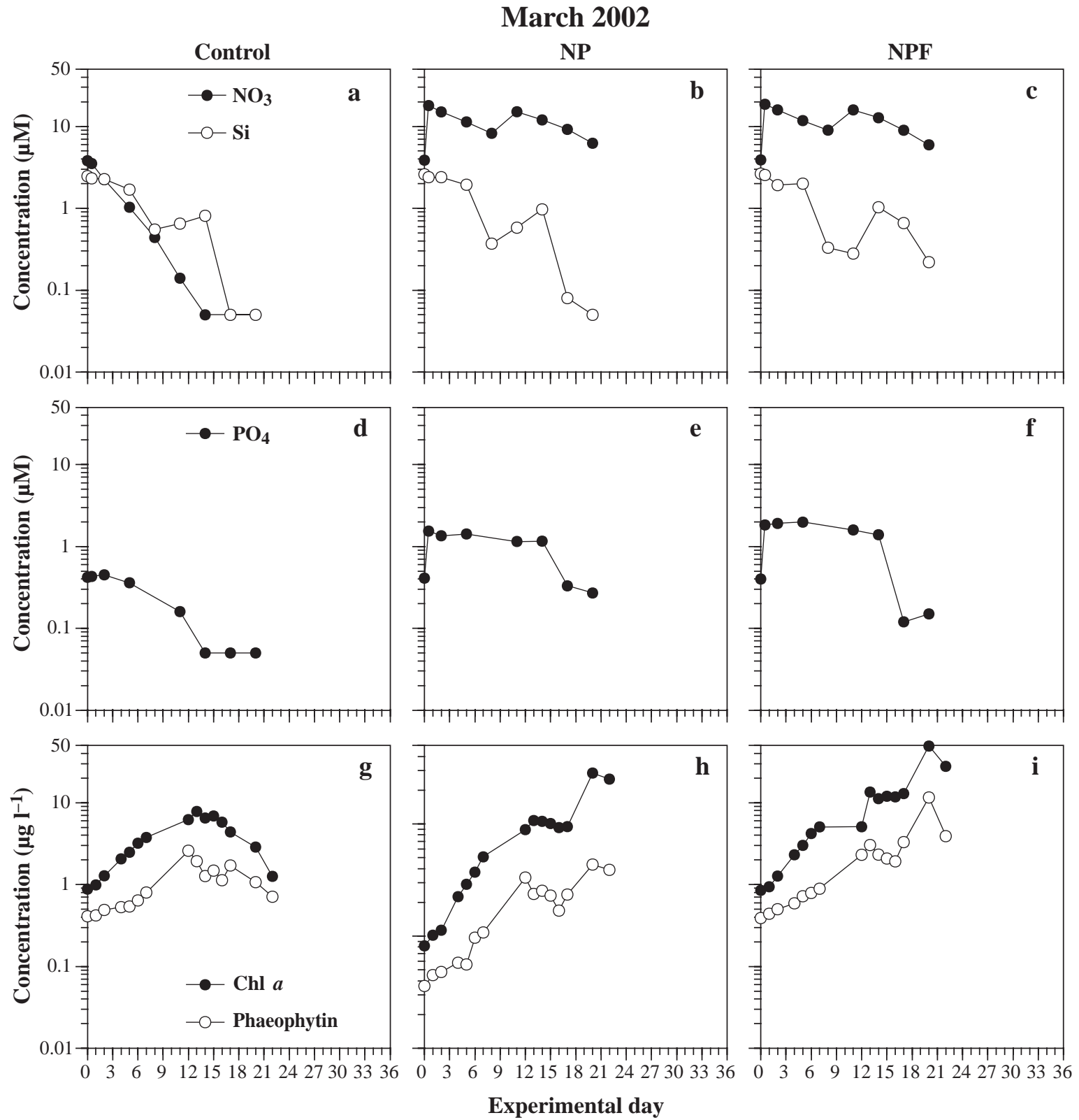

Experimental day

Fig. 2. Nutrients, chl $a$ and phaeophytin pigments in 2002 in $(a, d, g)$ unamended control $(b, c, h)$ fertilized $(N P ; b, e, h)$ and $(c, f, i) ~ N P$ fertilized plus cultured Phaeocystis pouchetii solitary cells. (a-c) Concentrations of $\mathrm{NO}_{3}$ and $\mathrm{Si}_{\text {; }}\left(\mathrm{d}-\mathrm{f}\right.$ ) concentration of $\mathrm{PO}_{4}$; ( $\mathrm{g}-\mathrm{i}$ ) concentrations of chl $\mathrm{a}$ and phaeophytin

fjord are shown in Figs. 2 to 4. Initial nutrient concentrations (N, P, Si) prior to fertilization in 2002 and 2003 were similar, but $\mathrm{N}$ concentrations $(3.9$ and $5.5 \mu \mathrm{M})$ and Si concentrations $(2.6$ and $5.1 \mu \mathrm{M})$, respectively, were slightly lower in 2002 than in $2003(\mathrm{~N}, \mathrm{p}=0.005$; $\mathrm{Si}_{1} \mathrm{p}=0.001$ ). Initial phosphorus concentrations in 2002 $(0.41 \mu \mathrm{M})$ and $2003(0.37 \mu \mathrm{M})$ were not significantly different $(p=0.11)$ from each other. During both years, nutrient concentrations after fertilization were not significantly different in any of the fertilized mesocosms (Figs. $2 \& 3$ ). The addition of 401 of expended $f / 2$ algal growth media along with the cultured Phaeocystis pouchetii solitary cells in the 2002 NPF mesocosm did not significantly elevate initial nutrient concentrations in the NPF versus NP treatments (Fig. 2).

In the unamended mesocosms, $\mathrm{N}$ and $\mathrm{P}$ concentrations decreased consistently for 15 to $20 \mathrm{~d}$, after which concentrations went below analytical detection limits $(0.05 \mu \mathrm{M})$. In 2003, Si in the unfertilized mesocosm declined somewhat more rapidly than in 2002, and fell below the detection limit after $10 \mathrm{~d}$. After the addition of nutrients to the fertilized mesocosms, nutrient con- 

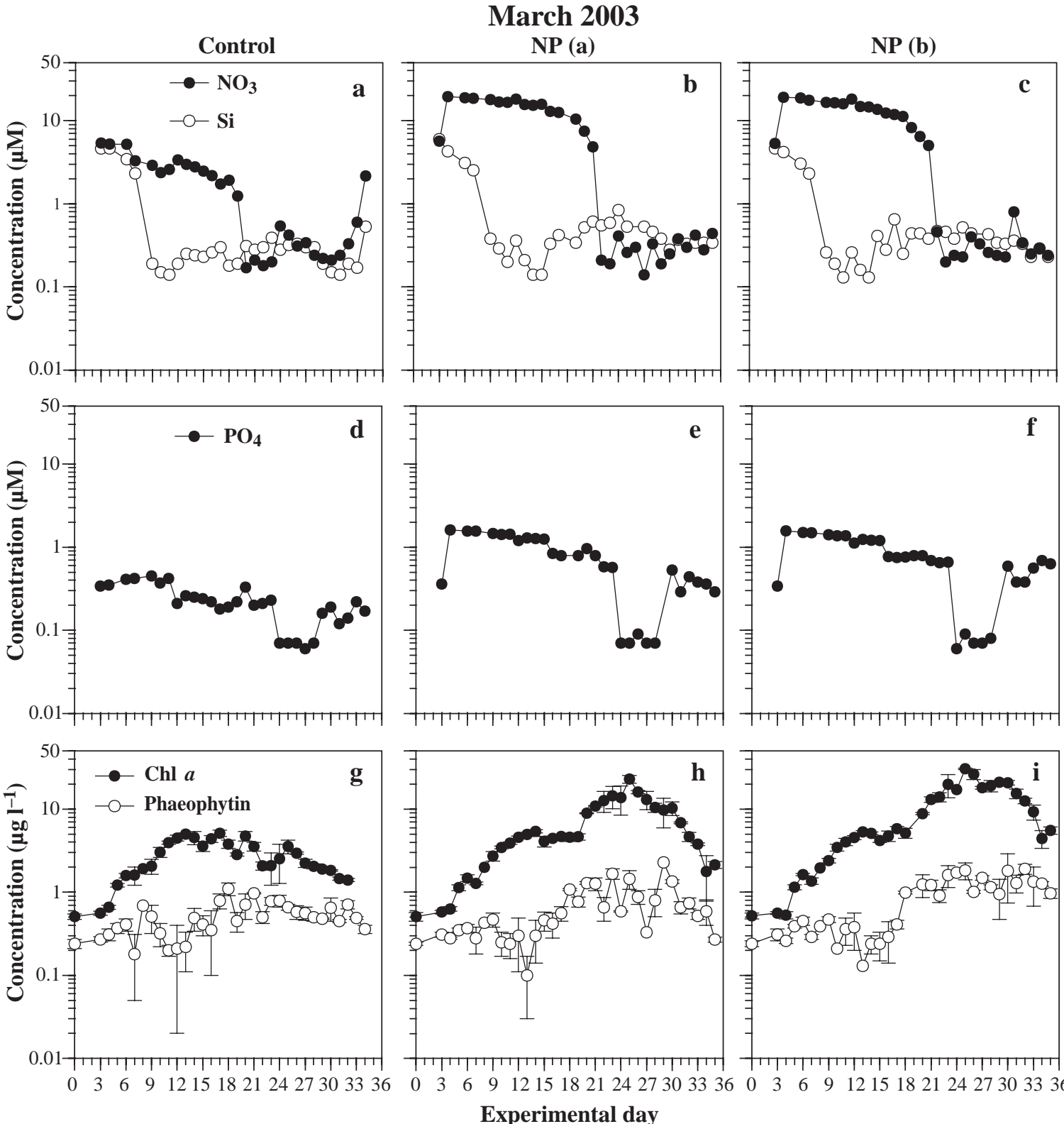

Experimental day

Fig. 3. Nutrients, chl $a$ and phaeophytin pigments in 2003 in $(a, d, g)$ unamended control and replicate (b,c,h) NP (a) fertilized and $\mathrm{NP}(\mathrm{b})$ fertilized mesocosms. (a-c) Concentrations of $\mathrm{NO}_{3}$ and $\mathrm{Si}_{i}(\mathrm{~d}-\mathrm{f})$ concentration of $\mathrm{PO}_{4}$; $(\mathrm{g}-\mathrm{i})$ mean $\pm \mathrm{SD}$ concentrations of chl $a$ and phaeophytin

centrations decreased over the course of the experiment, reaching detection limits after ca. 10 to $15 \mathrm{~d}$, similar to the unamended mesocosms (Figs. 2a,b \& $3 a, b)$. The decrease in $\mathrm{N}$ and $\mathrm{P}$ concentrations in the 2002 mesocosms was slowed by an additional spike of nutrients $\left(8 \mu \mathrm{M} \mathrm{NO}_{3}\right.$ and $\left.0.5 \mu \mathrm{M} \mathrm{PO}_{4}\right)$ on 12 March 2002.

Initial chl a concentrations were slightly higher in

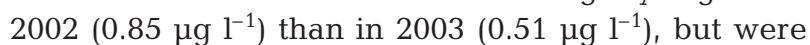
not significantly different from each other $(p=0.06)$. Likewise, initial phaeophytin concentrations were slightly higher in $2002\left(0.39 \mu \mathrm{g} \mathrm{l}^{-1}\right)$ compared to 2003

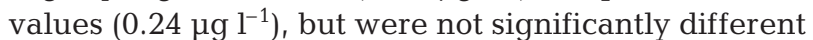
from each other $(p=0.06)$. In all mesocosms (unfertilized and fertilized), there was an initial small increase in chl a concentrations ranging from 1 to $5 \mu \mathrm{g} \mathrm{l}^{-1}$ which diminished in the unfertilized mesocosms and was succeeded by a dramatic increase in chl a concentrations to $25-30 \mu \mathrm{g} \mathrm{l}^{-1}$ in the fertilized mesocosms. In the NPF mesocosm (2002), Chl a concentrations reached a maximum of $49.1 \mathrm{\mu g} \mathrm{l}^{-1}$ on 24 March. Chl a concentrations peaked after $20 \mathrm{~d}$ in both fertilized meso- 

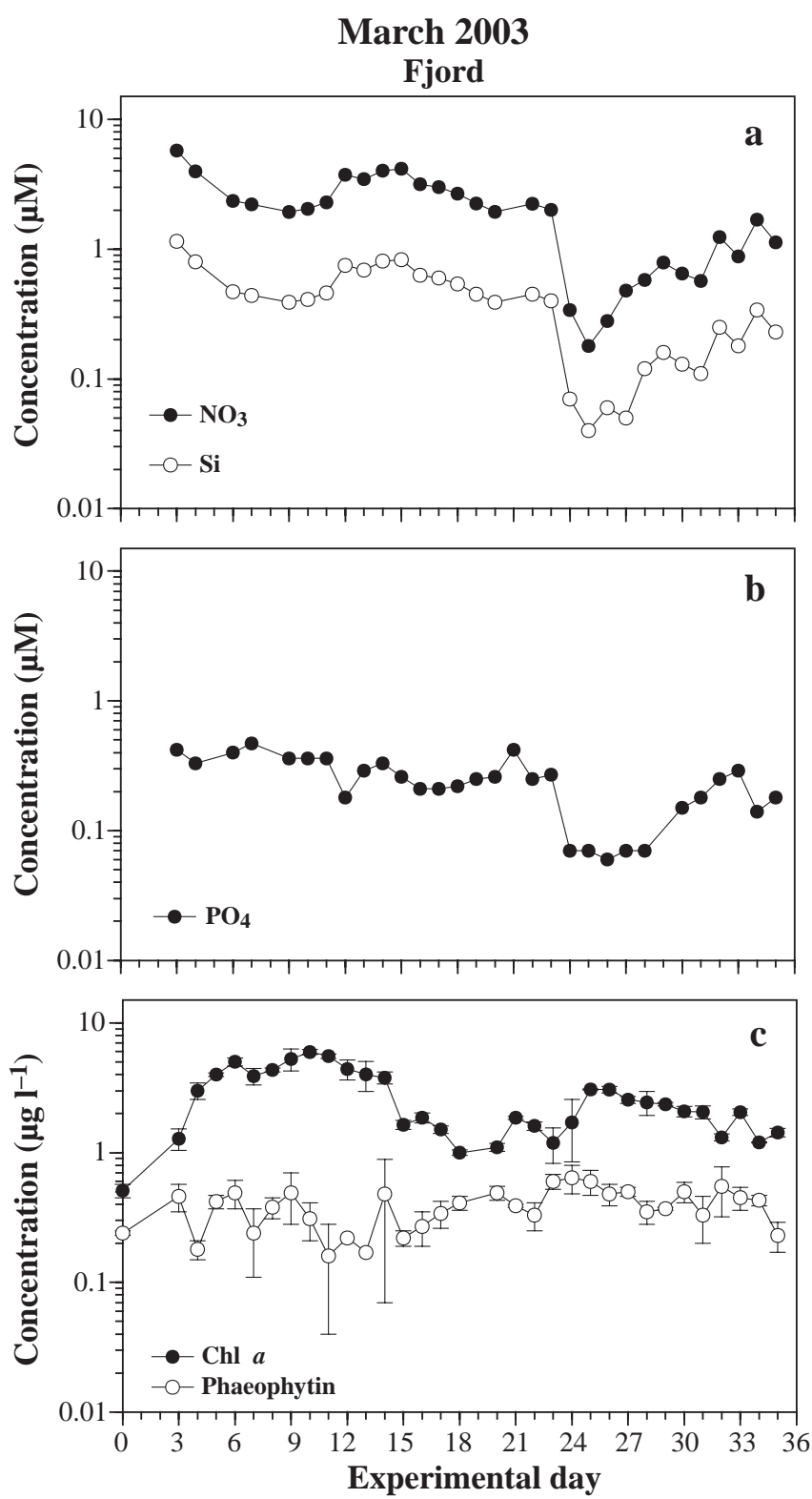

Fig. 4. Nutrients, chl a and phaeophytin pigment concentrations in Raunefjorden during 2003 study. (a) Concentrations of $\mathrm{NO}_{3}$ and $\mathrm{Si}_{i}(\mathrm{~b})$ concentration of $\mathrm{PO}_{4 i}$ (c) mean $\pm \mathrm{SD}$ concentrations of chl $a$ and phaeophytin

cosms in 2002 (24 March 2002). In 2003, chl a concentrations peaked $25 \mathrm{~d}$ after the experiment began, also on 24 March. During the longer experiment in 2003, a decline in chl a concentrations was observed in both fertilized mesocosms beginning $25 \mathrm{~d}$ after the start of the experiment on 24 March until the end of the experiment (3 April) when chl a concentrations were only slightly higher then initial concentrations, 1.4 and $2.1 \mathrm{\mu g} \mathrm{l}^{-1}$ in mesocosms NP(a) and NP(b), respectively (Fig. $3 g-\mathrm{i}$ ).

\section{Bacteria and viruses}

Both bacteria and viruses increased similarly in 2002 and 2003 studies, although slightly greater (but not significantly so, $\mathrm{p}=0.064$ ), net bacterial growth was observed in 2002 than in 2003 (Fig. 5a-c and 6a-c). Overall there were no differences in bacterial abundance or net production between the control and fertilized mesocosms, suggesting that bacterial populations did not respond directly to fertilization with inorganic nutrients ( $\mathrm{N}$ and $\mathrm{P}$ ) or the Phaeocystis pouchetii bloom by increasing in abundance. Bacterial abundance increased in the 2002 experiments from an average of $6.3 \pm 2.3 \times 10^{5} \mathrm{cells} \mathrm{ml}^{-1}$ at the start of the experiment to $3.95 \pm 1.2 \times 10^{6}$ cells ml $^{-1}$ after $21 \mathrm{~d}$ (6.3-fold). In 2003 bacterial abundance increased from an average of $1.2 \pm 0.3 \times 10^{6}$ cells ml $^{-1}$ at the start of the experiment to $4.9 \pm 1.2 \times 10^{6}$ cells ml $^{-1}$ after $35 \mathrm{~d}$ (4.1-fold). Apparent bacterial growth rates estimated from regression analysis of bacterial abundance were $1.9 \times 10^{5}$ cells d $^{-1}$ in $2002\left(\mathrm{r}^{2}=0.6\right)$ and $6.0 \times 10^{4}$ cells d $^{-1}$ in $2003\left(\mathrm{r}^{2}=0.2\right)$.

Similar to bacterial abundance, the total abundance of viral particles did not differ between unfertilized and fertilized mesocosms. Viral particle abundance increased from an average of $1.5 \pm 0.25 \times 10^{7}$ particles $\mathrm{ml}^{-1}$ at the start of the experiment to $6.4 \pm 6.0 \times 10^{7}$ particles $\mathrm{ml}^{-1}$ after $21 \mathrm{~d}$ (4.3-fold). In 2003 viral abundance increased from an average of $1.4 \pm 0.7 \times 10^{7}$ particles $\mathrm{ml}^{-1}$ at the start of the experiment to $3.95 \pm 0.1 \times$ $10^{7}$ particles $\mathrm{ml}^{-1}$ after $35 \mathrm{~d}$ (2.8-fold). The ratio of virus particles to bacterial cells (VBR) in all 2002 mesocosms varied between 6 and 39 and averaged $14 \pm 8$. In 2003 the VBR varied from 4.5 to 24.5 with an average of $9.9 \pm 5$.

\section{Phaeocystis}

Figs. 5d-f \& 6d-f show 3 forms of Phaeocystis pouchetii including solitary flagellated cells, colonies and total cells associated with colonies (non-motile single cells). Single non-motile cells associated with colonies were not determined in the 2002 experiment.

The initial abundance of flagellated cells was similar in $2002\left(207 \pm 12 \mathrm{ml}^{-1}\right)$ and $2003\left(130 \pm 96 \mathrm{ml}^{-1}\right)$ and increased after an initial lag period of ca. $8 \mathrm{~d}$ in 2002 and $15 \mathrm{~d}$ in 2003. In both sets of experiments, the abundance of solitary flagellated cells increased in each mesocosm and was within the same order of magnitude in fertilized and unfertilized treatments. During the lag phase of the 2002 experiment (Days 0 to 5), daily growth rates averaged $0.007 \mathrm{~d}^{-1}$, while average negative net growth rates of $-0.04 \mathrm{~d}^{-1}$ were calculated during the early portion (Days 0 to 15) of the 2003 study (Table 1). Maximum growth rates, which oc- 
March 2002
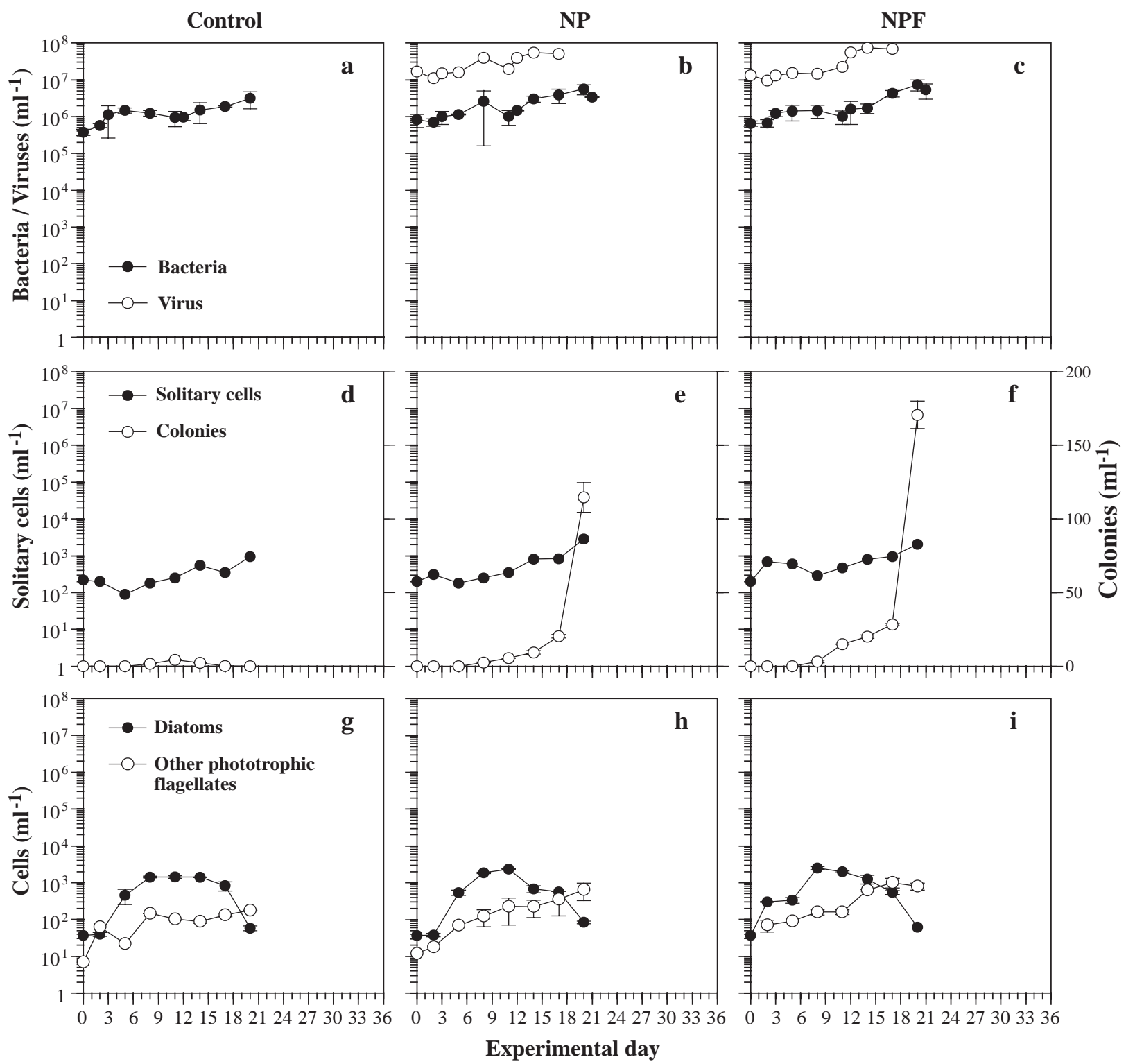

Experimental day

Fig. 5. Bacterioplankton, virioplankton, Phaeocystis pouchetii flagellated cells and colonies, other phototrophic flagellate cells, and diatoms during the 2002 study. (a-c) Abundance of bacterioplankton and virioplankton (virioplankton was not sampled in control); (d-f) abundance of $P$. pouchetii flagellated cells and colonies; $(g-i)$ mean \pm SD abundance of other phototrophic flagellate cells and diatoms

curred after the lag phase, varied from 0.33 to $1.22 \mathrm{~d}^{-1}$ with an overall average maximum growth rate of $0.21 \pm 0.10 \mathrm{~d}^{-1}$ (Table 1). There was no significant difference in the average or maximum growth rates of solitary flagellated cells in fertilized versus unfertilized treatments $(p=0.51)$ or between years $(p=0.09)$. In the 2003 study, when biomass was estimated, Phaeocystis pouchetii single flagellated cells accounted for only $6.3 \pm 1.2 \mu \mathrm{C} \mathrm{l}^{-1}$ at their maximum densities, and this was similar between the mesocosms (Fig. $7 \mathrm{a}-\mathrm{C}$ ).
Phaeocystis pouchetii colonies were not detected in any of the 2002 mesocosms at the initiation of the experiments and were present in very low abundance (ca. 6 colonies $\mathrm{ml}^{-1}$ ) at the start of the experiments in 2003. Colonies developed in each year and in all mesocosms, although colony abundance in the unfertilized mesocosms was very low. Colonies first appeared in the 2002 mesocosms in each treatment $8 \mathrm{~d}$ from the initiation of the experiment on 12 March. In 2003, the concentration of colonies began to increase in the fer- 
Table 1. Average and (maximum) instantaneous net daily growth rates $\left(\mathrm{d}^{-1}\right)$ for $\mathrm{chl} a$, bacteria and Phaeocystis pouchetii flagellated cells and colonies in 2002 and 2003 studies. NP: nitrate and phosphate; NPF: nitrate + phosphate + P. pouchetii. Initiation: no colonies present or net increase in abundance; during 2002 this phase was from Days 0 to 5, during 2003 from Days 0 to 15 . Exponential: colonies present and colonies exhibiting net increase in abundance; during 2002, this phase was from Days 6 to 22, during 2003 from Days 7 to 29. Decay: colonies present and colonies exhibiting net decrease in abundance; during 2002 no decay phase was observed, during 2003 this phase was from Days 30 to 35. na: data not available

\begin{tabular}{|c|c|c|c|c|c|c|c|}
\hline \multirow[t]{2}{*}{ BloomPhase } & \multicolumn{3}{|c|}{$\longrightarrow$ Series 1 (2002) } & \multicolumn{4}{|c|}{ — Series 2 (2003) — } \\
\hline & Control & NP & NPF & Fjord & Control & NP(a) & $\mathrm{NP}(\mathrm{b})$ \\
\hline \multicolumn{8}{|l|}{ Chl $a\left(\mu g \mathrm{l}^{-1}\right)$} \\
\hline Initiation & $0.21(0.25)$ & $0.25(0.35)$ & $0.25(0.30)$ & $0.08(0.85)$ & $-0.05(0.61)$ & $0.06(0.60)$ & $0.12(0.78)$ \\
\hline Exponential & $-0.04(0.25)$ & $0.13(0.56)$ & $0.13(0.97)$ & $0.03(0.59)$ & $-0.10(0.51)$ & $-0.25(0.65)$ & $0.12(0.58)$ \\
\hline Decay & na & na & na & $-0.08(0.45)$ & $-0.10(-0.03)$ & $-0.25(0.18)$ & $0.12(0.22)$ \\
\hline \multicolumn{8}{|c|}{ P. pouchetii flagellated cells (cells $\mathrm{ml}^{-1} \mathrm{~d}^{-1}$ ) } \\
\hline Initiation & $-0.18(-0.05)$ & $-0.02(0.22)$ & $0.22(0.62)$ & na & $-0.05(0.10)$ & $0.00(0.00)$ & $-0.07(0.46)$ \\
\hline Exponential & $0.16(0.33)$ & $0.18(0.41)$ & $0.08(0.26)$ & na & $0.17(0.69)$ & $0.32(0.62)$ & $0.34(1.22)$ \\
\hline Decay & na & na & na & na & 0.18 & -0.20 & -0.05 \\
\hline \multicolumn{8}{|c|}{ Phaeocystis colonies ( $\mathrm{col} \mathrm{ml} \mathrm{l}^{-1} \mathrm{~d}^{-1}$ ) } \\
\hline Initiation & 0.00 & 0.00 & 0.00 & $0.17(0.77)$ & $-0.09(0.17)$ & $-0.07(0.034)$ & $-0.06(0.22)$ \\
\hline Exponential & $0.00(0.32)$ & $0.32(0.58)$ & $0.33(0.60)$ & $0.06(0.10)$ & $0.17(0.48)$ & $0.27(1.02)$ & $0.32(0.42)$ \\
\hline Decay & na & na & na & $-0.14(0.23)$ & $-0.23(-0.12)$ & $0.15(-0.06)$ & $-0.02(-0.02)$ \\
\hline \multicolumn{8}{|c|}{ Bacteria $\times 10^{5}\left(\right.$ cells ml $\left.{ }^{-1} \mathrm{~d}^{-1}\right)$} \\
\hline Initiation & $2.34(2.84)$ & $0.71(1.34)$ & $1.67(2.24)$ & na & $0.74(3.01)$ & $1.11(4.91)$ & $0.95(3.07)$ \\
\hline Exponential & $1.69(2.60)$ & $2.34(5.03)$ & $4.56(6.96)$ & na & $1.43(1.70)$ & $1.66(2.49)$ & $2.25(3.03)$ \\
\hline Decay & na & na & na & na & na & 0.94 (na) & 1.19 (na) \\
\hline
\end{tabular}

tilized treatments on 17 March, ca. $18 \mathrm{~d}$ after the start of the experiment. Maximum colony concentrations were similar in all the fertilized treatments $(145 \pm 25$ colonies $\left.\mathrm{ml}^{-1}\right)$ and was significantly higher $(\mathrm{p} \leq 0.001)$ than maximum colony concentrations in the unfertilized mesocosms $\left(11 \pm 3\right.$ colonies $\left.\mathrm{ml}^{-1}\right)$. The rate at which colonies increased in the fertilized treatments is shown in Table 1. Net colony increase in the lag phases were zero or slightly negative during both years and in all treatments. During the exponential phase, the rate of net colony increase averaged $0.31 \mathrm{~d}^{-1}$ in the fertilized treatments and $0.085 \mathrm{~d}^{-1}$ in the unamended mesocosms (Table 1). In the 2003 study, when estimates of biomass were calculated for colonial $P$. pouchetii cells, these cells accounted for $648 \pm 167 \mu \mathrm{C}^{-1}$ at their maximum densities in the fertilized mesocosms (Fig. 7b,c). This biomass represents over 100 times the biomass of single cells in these same mesocosms. Even in the unfertilized mesocosm, where the abundance of Phaeocystis colonies was low, the estimated biomass of colonial cells was ca. 14 times higher then the average biomass of single cells in these mesocosms (Fig. 7a).

Colony dispersion was not observed during 2002, when the experiment was terminated after $21 \mathrm{~d}$ (13 d after colonies were first detected), but was seen during the 2003 study beginning 24 to $27 \mathrm{~d}$ after initiation of the experiment. By the time the experiment was terminated on 3 April, colony concentrations averaged $66 \pm 38$ colonies $\mathrm{ml}^{-1}$ in the fertilized mesocosms. Negative net colony increase rates were calculated during this period (Table 1).

\section{Microplankton}

All phototrophic microplankton groups in addition to Phaeocystis pouchetii are shown in Figs. $5 \mathrm{~g}-\mathrm{i}, 6 \mathrm{~g}-\mathrm{i} \&$ 7. The diatom community, including chain-forming and solitary species, showed similar patterns in all mesocosms, reaching similar abundances in fertilized $\left(4.8 \pm 2.8 \times 10^{3}\right.$ cells $\left.\mathrm{ml}^{-1}\right)$ and unfertilized $(4.3 \pm 4.1 \times$ $10^{3}$ cells $\mathrm{ml}^{-1}$ ) treatments and during both years. In general, diatom communities were low at the start of both experiments, reached a maximum early in the experiments, and declined when $\mathrm{Si}$ was depleted. In 2002 the diatom community was dominated by a mixture of chain-forming taxa including Skeletonema costatum, Leptocylindrus sp., Chaetoceros socialis and Thalassiosira sp. Other diatoms that occurred to a lesser extent included Nitzschia sp. and Coscinodiscus sp. Virtually all the same species that were present in 2002 were also present in 2003, but in 2003 the diatom community was largely dominated by Chaetoceros socialis. In 2003, when biomass estimates were calculated, maximum averaged biomass estimate on 11 March (Day 12) in the unfertilized and nutrient amended treatments was $265 \pm 34 \mu \mathrm{g} \mathrm{Cl}^{-1}$ (Fig. 7d-f).

The abundance of phototrophic flagellate species $>5 \mu \mathrm{m}$ other than Phaeocystis pouchetii enumerated during the 2002 experiments are shown in Fig. 5g-i. All phototrophic flagellate species between 2 and $9 \mu \mathrm{m}$ were enumerated during the 2003 experiments and are shown in Fig. $6 g-i$. The abundance of the photo- 

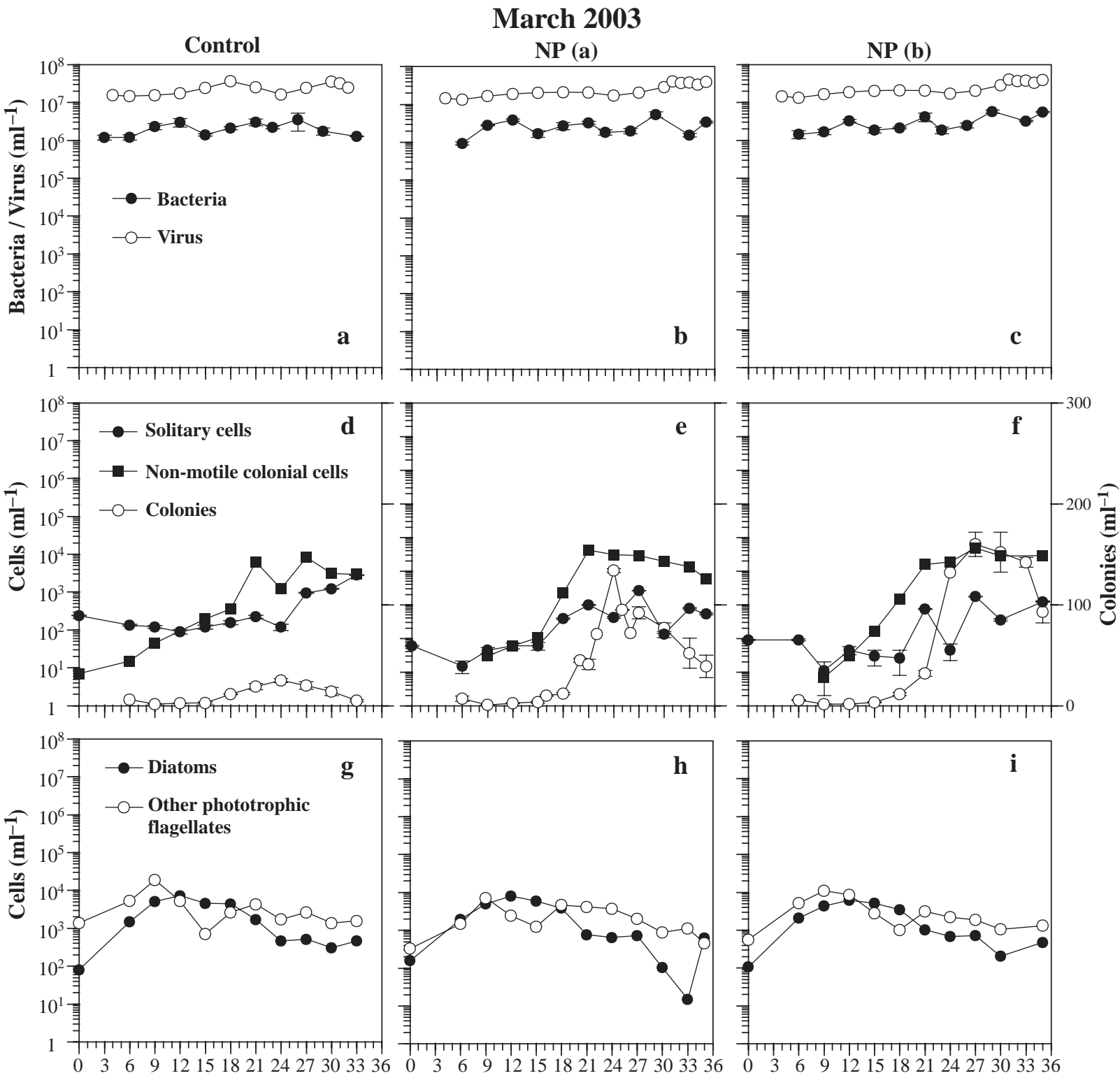

Experimental day

Fig. 6. Bacterioplankton, virioplankton, Phaeocystis pouchetii flagellated cells, non-motile colonial cells, colonies, other phototrophic flagellate cells and diatoms during 2003 study. (a-c) Abundance of bacterioplankton and virioplankton; (d-f) abundance of $P$. pouchetii flagellated cells, non-motile Phaeocystis pouchetii colonial cells and colonies; $(g-\mathrm{i})$ mean $\pm \mathrm{SD}$ abundance of other phototrophic flagellate cells and diatoms

trophic flagellates (whether only species $>5 \mu \mathrm{m}$ or those between 2 and $9 \mu \mathrm{m}$ were counted) was not differentially affected by fertilization treatment and the subsequent colonial bloom of $P$. pouchetii. During 2002, microflagellate populations increased throughout the experiment, although absolute number of these species was relatively low $\left(614 \pm 418 \mathrm{ml}^{-1}\right)$. The dominant larger phototrophic flagellate species included Chrysochromulina spp., Apedinella spp. and Pyramimonas spp. In 2003 a similar pattern to the 2002 study was observed, but in addition to a general increase in larger phototrophic flagellate species, smaller species ( 2 to $3 \mu \mathrm{m}$ ) that were counted in these studies dominated the microflagellate community. These small phototrophic flagellates bloomed early in the experiment coincident with the diatom bloom, reaching maximum concentrations on the order of $10^{4}$ cells $\mathrm{ml}^{-1}$. Although these organisms dominated the abundance of this group, they were too small to be definitively identified by epifluoresence microscopy. In addition to the larger species that dominated the mesocosms during the 2002 studies, Eutreptiella eupharyngea and 

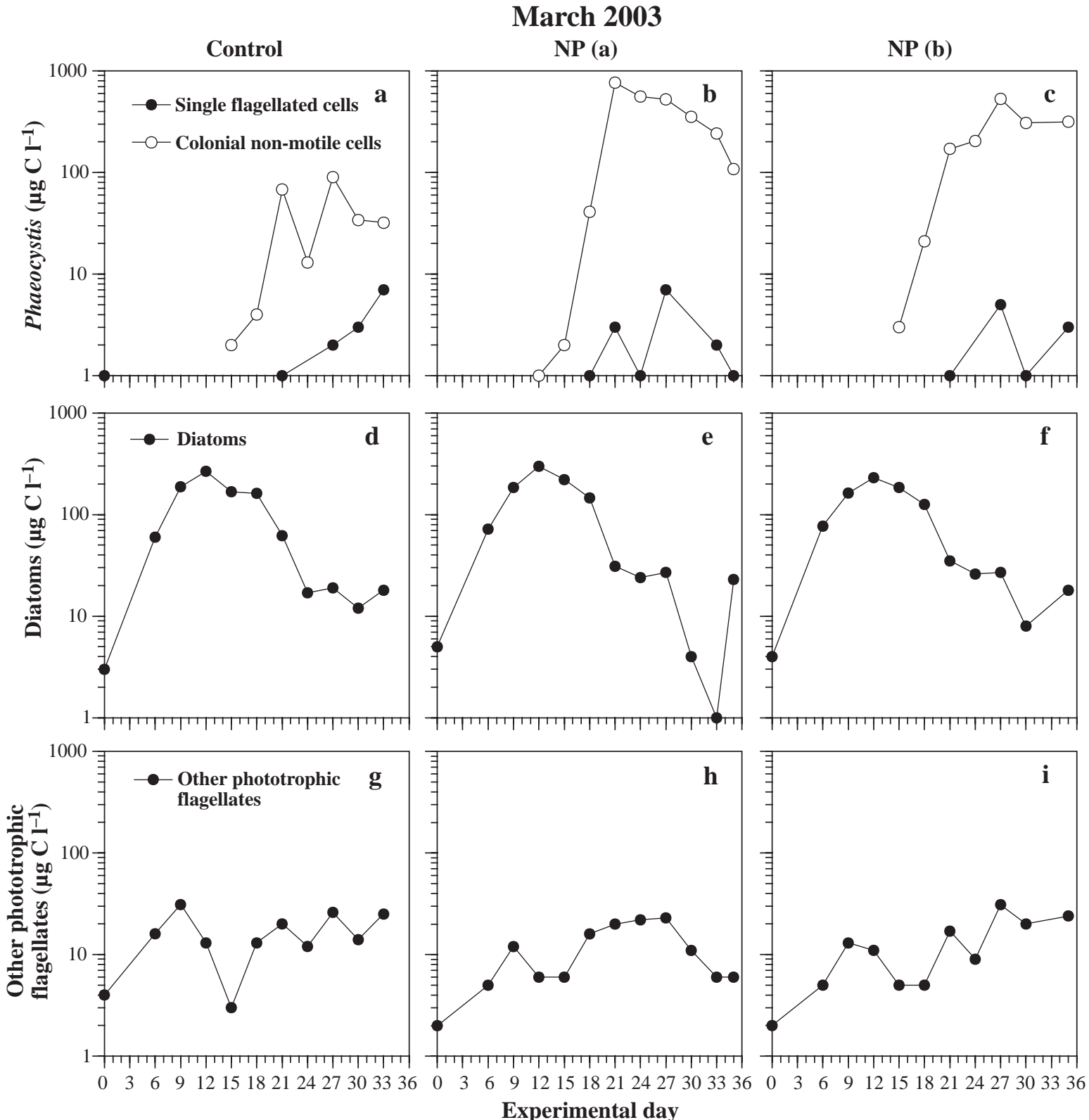

Fig. 7. Estimated biomass of Phaeocystis pouchetii flagellated cells, non-motile $P$. pouchetii colonial cells, other phototrophic flagellated cells and diatoms during 2003 study. (a-c) Estimated biomass of $P$. pouchetii flagellated cells and non-motile $P$. pouchetii colonial cells; $(\mathrm{d}-\mathrm{f})$ diatoms ; $(\mathrm{g}-\mathrm{i})$ other phototrophic flagellated cells

Pachysphaera pelagica were important members of the microflagellate community during the 2003 experiment. Estimates of phototrophic flagellate biomass are shown in Fig. $7 \mathrm{~g}-\mathrm{i}$ and reflect the relative importance of the larger flagellate species which, as was observed in 2002, generally increased throughout the study.

The abundance of heterotrophic flagellates $(>5 \mu \mathrm{m})$ and heterotrophic nano-flagellates $(<5 \mu \mathrm{m})$ are shown in Figs. 8a-c \& 9a-c. During both years the abundance of these species generally increased over the course of the experiments and was not differentially influenced by the nutrient fertilization and the resultant Phaeocystis pouchetii bloom. The average abundance of heterotrophic nanoflagellates increased from $358 \pm 124$ to $1736 \pm 387$ cells ml$^{-1}$ in the 2002 and from $228 \pm 293$ to $3798 \pm 1952$ cells ml ${ }^{-1}$ in 2003 . The average maximum biomass of the heterotrophic nanoflagellates and of the larger heterotrophic flagellates was roughly equivalent

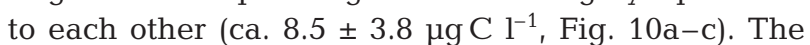
heterotrophic nanoflagellate community was dominated by small $(2$ to $3 \mu \mathrm{m})$ species which could not be identified 

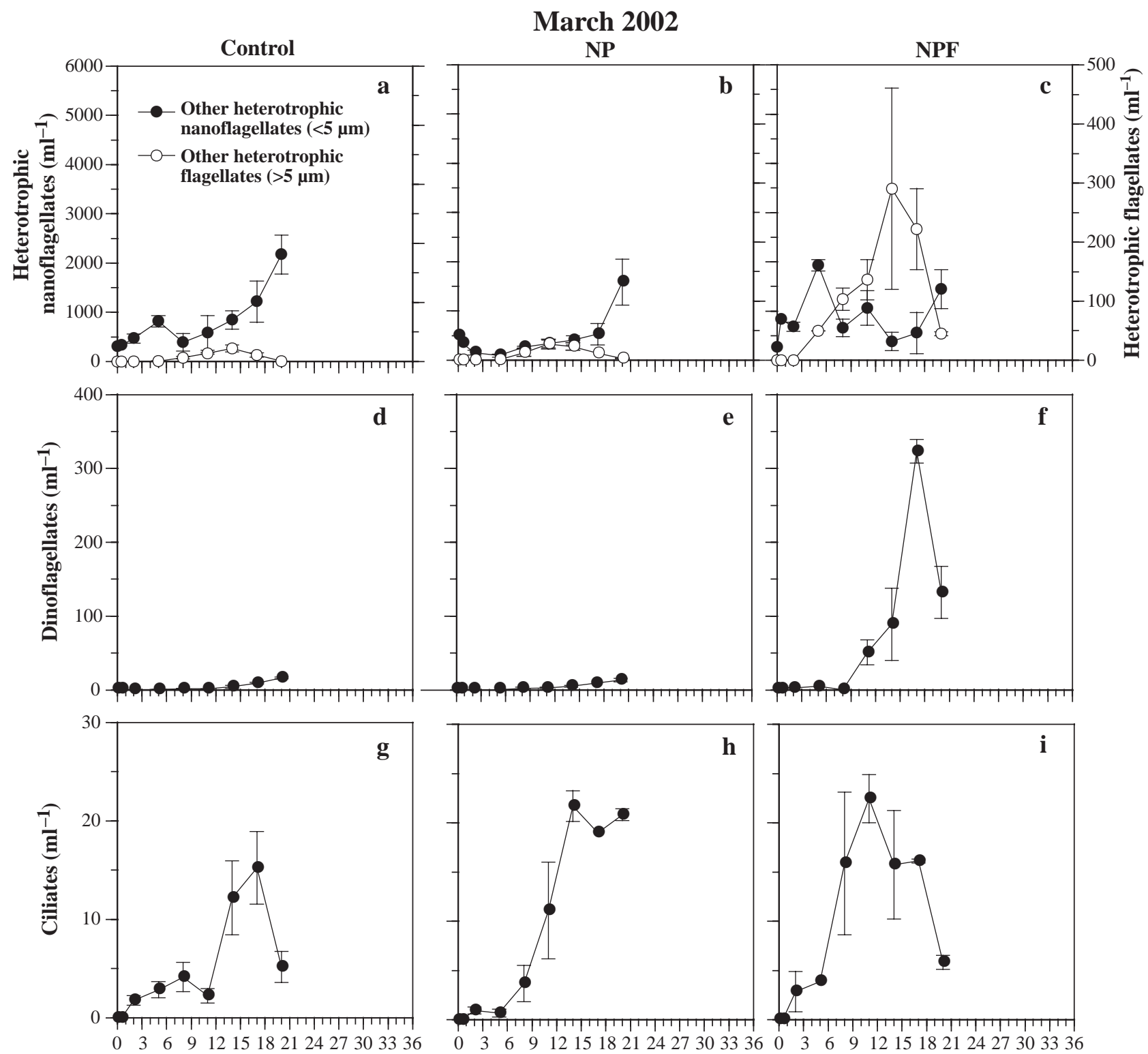

Experimental day

Fig. 8. Mean \pm SD abundance of heterotrophic nanoflagellates $(<5 \mu \mathrm{m})$, other heterotrophic flagellates $(>5 \mu \mathrm{m}$, not including dinoflagellates), dinoflagellates and ciliates during 2002 study. (a-c) Abundance of heterotrophic nanoflagellates and other heterotrophic flagellates; $(\mathrm{d}-\mathrm{f})$ abundance of dinoflagellates; $(\mathrm{g}-\mathrm{i})$ abundance of ciliates

by epifluoresence microscopy. The larger heterotrophic flagellates were also largely dominated by unidentified species. During the 2002 experiment, Rhizomonas sp. was identified in the mesocosms and often observed associated with the chain-forming diatom Leptocylindrus sp., especially during the early part of the experiment when diatoms were relatively abundant.

Dinoflagellates were found at relatively low concentrations in all the mesocosms regardless of the year or fertilization treatment. Dinoflagellate abundance generally increased throughout the experiment (Figs. $8 \mathrm{~d}-\mathrm{f}$
\& $9 d-f)$. The one exception to this generality was in NPF treatment during the 2002 experiment where dinoflagellate abundance reached $323 \pm 16$ cells ml $^{-1}$ on 21 March near the end of the experiment (Fig. 8f). Dinoflagellate communities were dominated by Protoperidinium bipes, P. pellucidum and several species of Gyrodinium. The biomass of dinoflagellate communities, estimated based on the 2003 study, was relatively low and generally increased from 1 to $3 \mu \mathrm{C} \mathrm{Cl}^{-1}$ at the start of the experiment to $10-30 \mu \mathrm{g} \mathrm{Cl}^{-1}$ near the end of the study (Fig. 10d-f). 

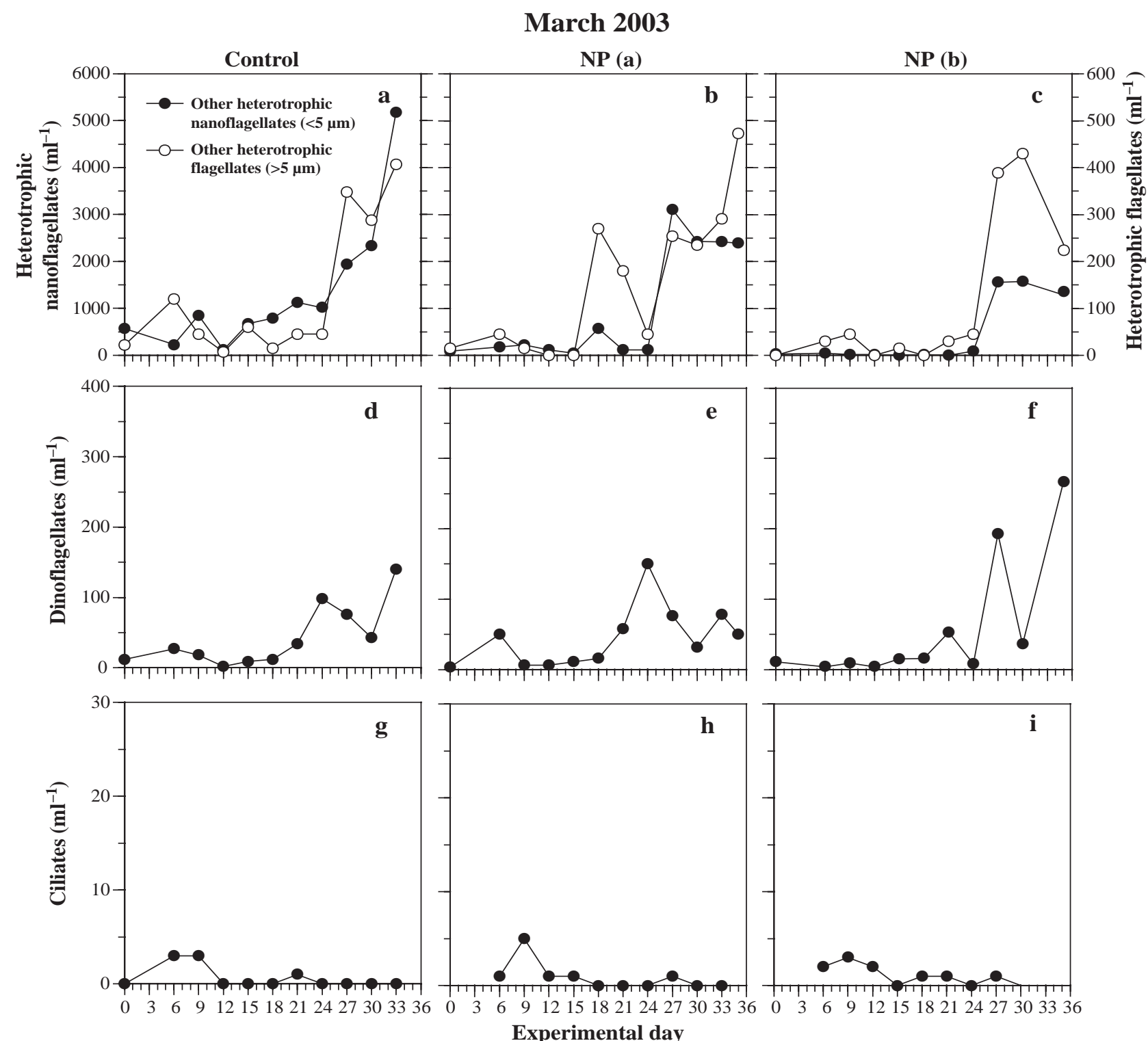

Experimental day

Fig. 9. Abundance of heterotrophic nanoflagellates $(<5 \mu \mathrm{m})$, other heterotrophic flagellates $(>5 \mu \mathrm{m}$, not including dinoflagellates), dinoflagellates and ciliates during 2003 study. (a-c) Abundance of heterotrophic nanoflagellates and other heterotrophic flagellates; (d-f) abundance of dinoflagellates; $(g-i)$ abundance of ciliates

\section{Mesozooplankton}

The overall concentrations of mesozooplankton were low, similar in both years, and were apparently not impacted by the fertilization treatment and the ensuing colonial Phaeocystis pouchetii bloom (Fig. 11). During the 2002 experiment the initial mesozooplankton community was dominated by barnacle nauplii (Balanus sp.) in all mesocosms. Some of these barnacle larvae were found in metamorphic forms during the experiment and then disappeared from the water column. At the termination of the experiment, the inside walls of the mesocosms were examined for settled barnacles, however, none were found. During the 2003 experiment barnacle larvae were not present and copepodite stages of calanoid copepods dominated the mesozooplankton biomass (Fig. 11b). The small numbers of feeding mesozooplankton other than these 2 categories were mostly composed of molluscan meroplankton and rotifers. The copepods were dominated by CI-CIV stages of Calanus finmarchicus, with a small number of the calanoid copepod Paracalanus parvus, the cyclopoid copepod Oithona spp. and a small number of benthic harpacticoid copepods. The observation that the mesozooplankton did not respond by increased biomass or nauplii production in the presence 

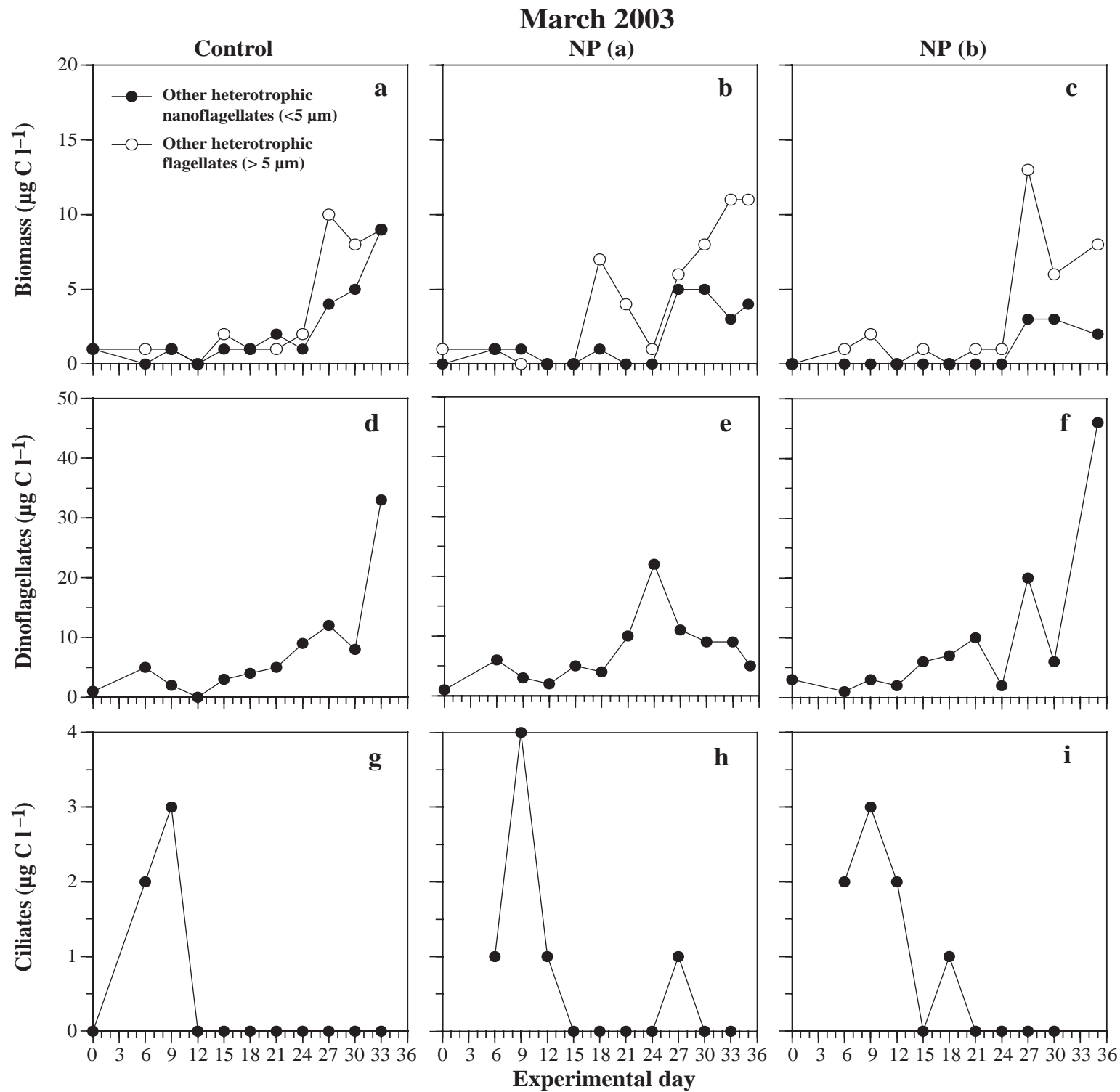

Fig. 10. Estimated biomass of heterotrophic nanoflagellates $(<5 \mu \mathrm{m})$, heterotrophic flagellates $(>5 \mu \mathrm{m}$, not including dinoflagellates), dinoflagellates, and ciliates during 2003 study. $(\mathrm{a}-\mathrm{c})$ Biomass of heterotrophic nanoflagellates and other heterotrophic flagellates; $(\mathrm{d}-\mathrm{f})$ abundance of dinoflagellates; $(\mathrm{g}-\mathrm{i})$ abundance of ciliates

of a significant algal (Phaeocystis pouchetii) bloom supports the hypothesis that in nature Phaeocystis spp. (single cells or colonies) are not readily grazed and do not contribute substantially to the biomass of higher trophic levels.

\section{Phaeocystis pouchetii colony formation studies}

During the 2002 experiment, 3 incubation studies utilizing single cells from the NPF mesocosm were performed in order to estimate the formation rates of new small colonies from Phaeocystis pouchetii solitary cells (Fig. 12). The 3 studies began on 10, 13 and 16 March, and each experiment lasted for $7 \mathrm{~d}$. In all experiments new colonies increased approximately linearly over time in the well plates, with significantly $(p<0.05)$ more colonies appearing in the wells with added diatomaceous earth than in controls. Mean rates of new colony appearance in the 3 experiments, calculated from linear regression of the data in Fig. 12, were 1.50, 1.85 and 1.26 colonies $\mathrm{d}^{-1}$ without diatomaceous earth, and $2.77,2.69$ and 2.62 colonies $\mathrm{d}^{-1}$ in the 3 colonies with diatomaceous earth (Table 1). Correlation coefficients for the six linear regressions ranged from $\mathrm{r}^{2}=$ 0.96 to 0.99 , and the differences between slopes of controls and those with added diatomaceous earth were significant $(\mathrm{p}<0.05)$. 
2002

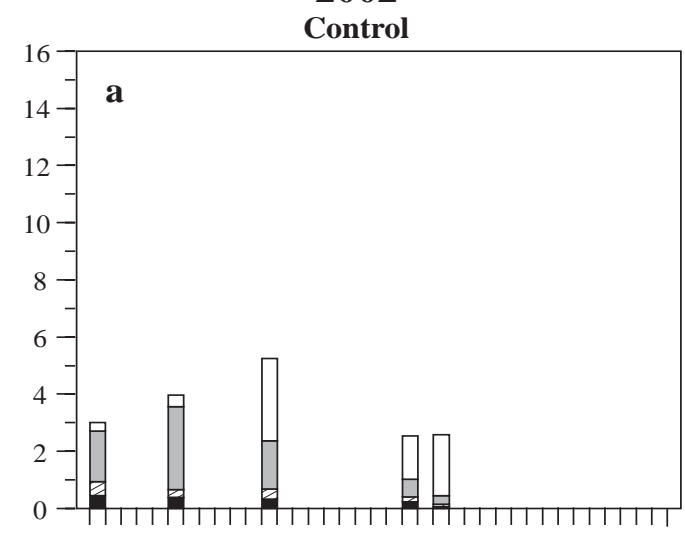

NP
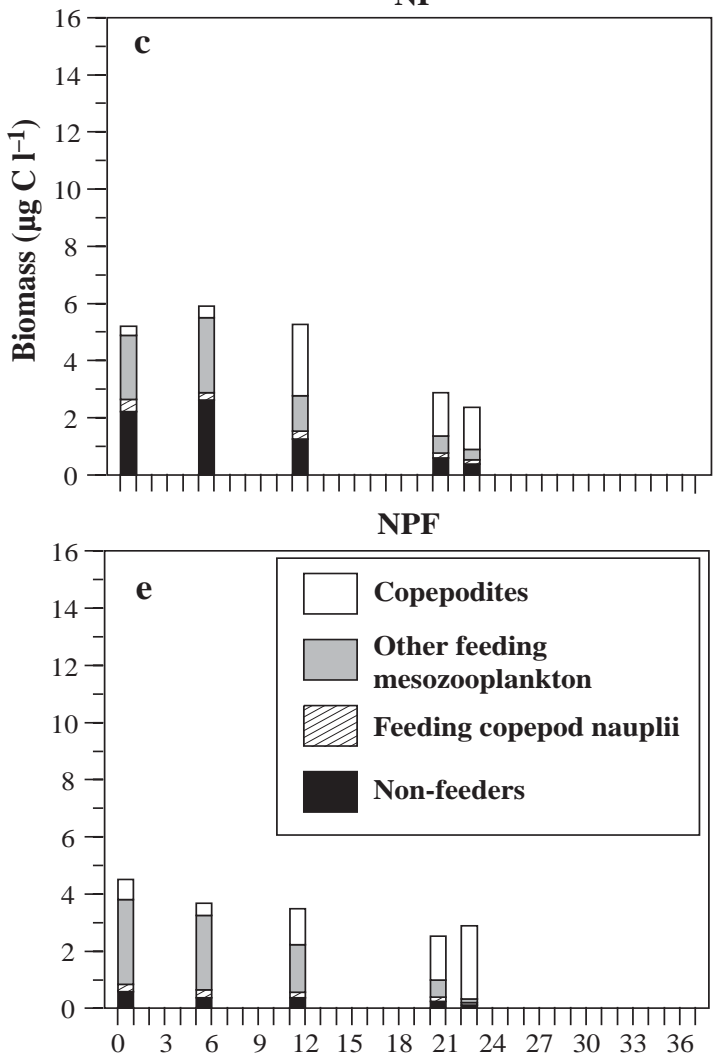

2003

Control

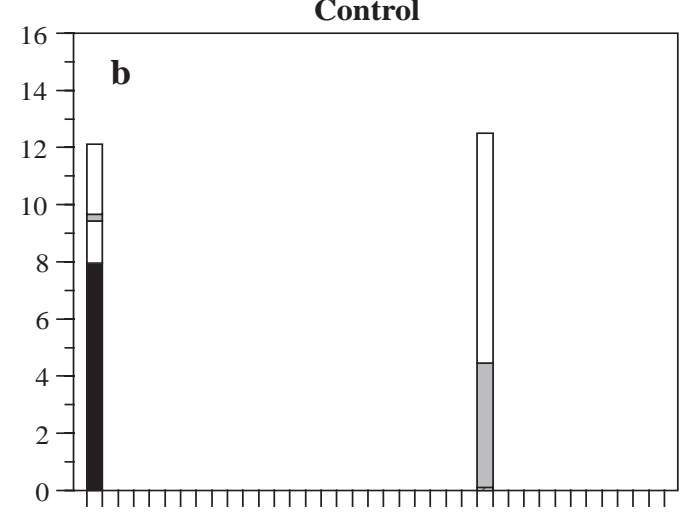

NP (a)

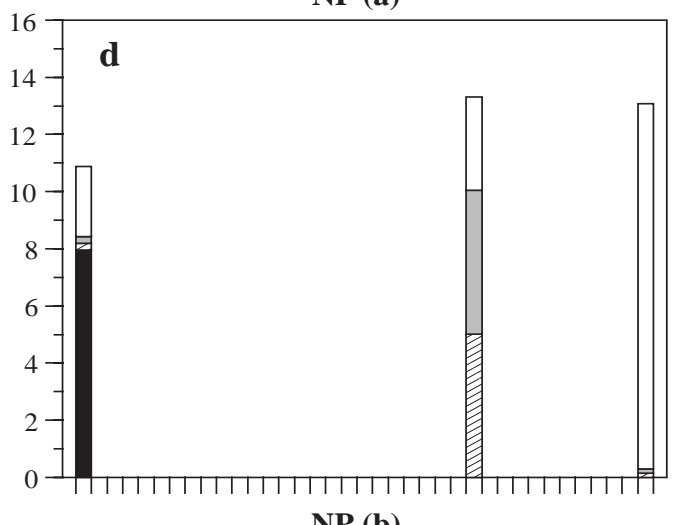

NP (b)

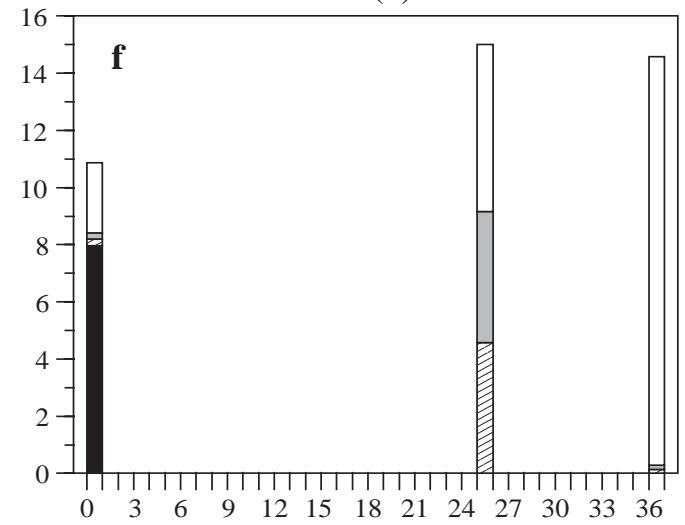

\section{Experimental day}

Fig. 11. Estimated biomass of mesozooplankton in (a,c,e) 2002 and (b, d, f) 2003 mesocosm studies. (a,b) Unfertilized control mesocosms; (c-f) fertilized mesocosms. In 2002, in addition to fertilization, 1 mesocosm (NPF) was further amended with Phaeocystis pouchetii solitary cells. Estimated biomass was comprised of copepodites (CI adults) consisting mainly of Calanus finmarchicus, other feeding mesozooplankton, feeding copepod nauplii consisting mainly of C. finmarchicus and non-feeding mesozooplankton consisting primarily of copepod eggs and Calanus sp. stages NI to II. During 2002 study, Balanus sp. larvae comprised majority of 'other feeding mesozooplankton' category

\section{DISCUSSION}

In order to investigate how the base of the planktonic food web (virus to mesozooplankton) responded to a colonial bloom of the prymnesiophyte alga Phaeocystis pouchetii, we compared the biomass development in fjord water enclosed in situ with either no further treat- ment (controls) or added nitrate and phospate (NP) and cultured solitary cells of $P$. pouchetii (NPF). We compare results from 2 independent mesocosm studies conducted in the early spring (March), but in 2 successive years to allow for a robust interpretation of the gross effects of simple manipulated environmental variables on subsequent complex general patterns in the plankton devel- 
opment. Mesocosms provide an ideal tool for studying plankton communities because they (1) simulate relatively realistic and complex communities and community dynamics (at least compared to laboratory scale systems), (2) allow manipulation of specific factors, and (3) allow the same water mass to be sampled over time (Duarte et al. 1997). Using this model system we also investigated whether the addition of $P$. pouchetii solitary cells that were in late log growth phase would accelerate the induction of colony formation, quantified $P$. pouchetii colony formation rates under realistic conditions, and explored how a typical high latitude marine food web responded to $P$. pouchetii colony domination.
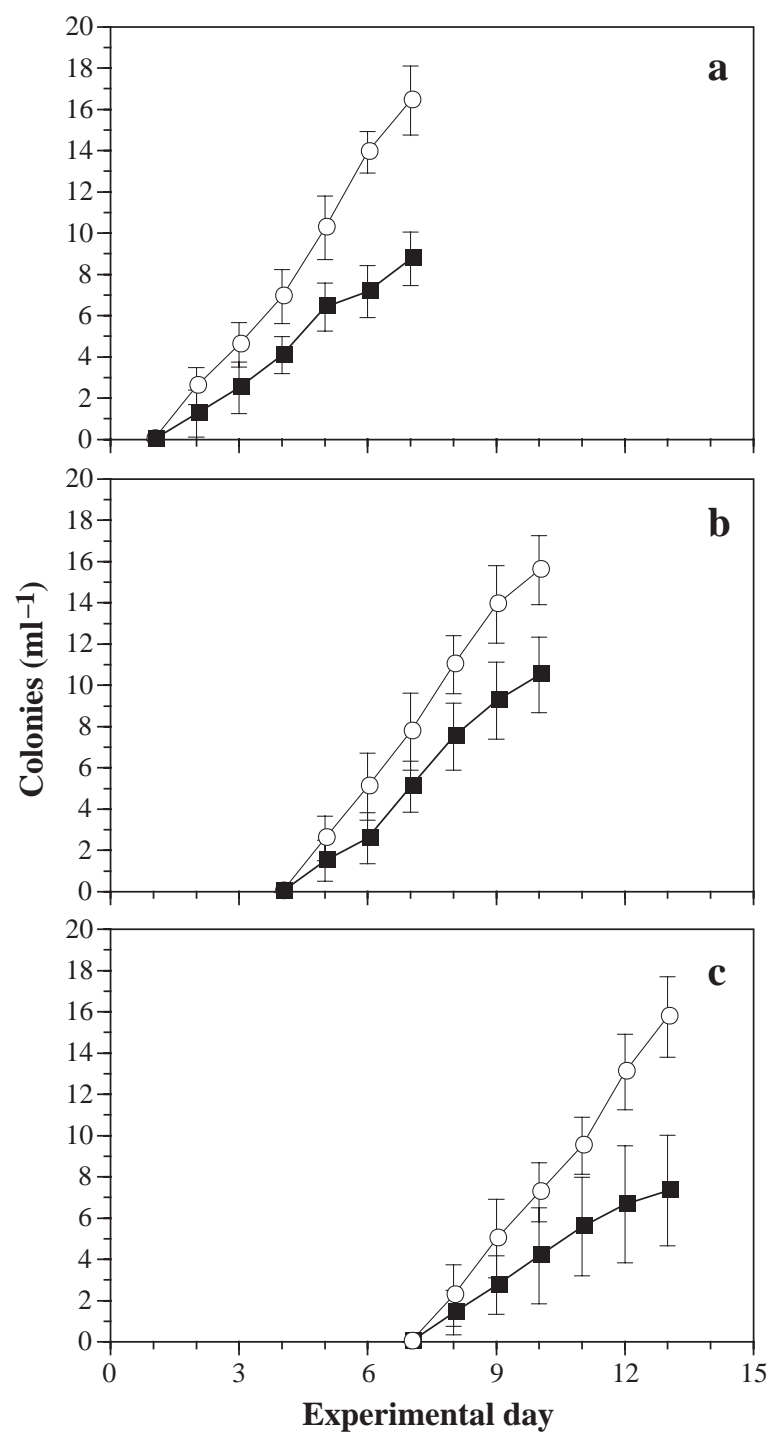

Fig. 12. Formation of Phaeocystis pouchetti colonies in water collected from the NPF mesocosm (2002) in (O) presence and ( $\square$ ) absence of diatomaceous earth. Each experiment was monitored for $7 \mathrm{~d}$ with water removed from mesocosm on (a) 1st day of study (10 March 2002), (b) 3rd day of study (13 March 2002) and (c) 7th day of study (16 March 2002)

\section{Simulating colonial blooms of Phaeocystis pouchetii}

Blooms of Phaeocystis pouchetii in northern latitudes have historically been reported as those of colonies, simultaneously with or just after spring blooms of chain-forming diatoms such as S. costatum, Leptocylindrus spp., and Chaetoceros spp. (Heimdal 1974, Eilertsen et al. 1981, Erga 1989). In Norwegian fjords, colonies of $P$. pouchetii are typically abundant between February and May, but may also occur in high numbers during the fall (Eilertsen et al. 1981). P. pouchetii often dominates over diatoms in waters with low silicate concentrations $(<2 \mu \mathrm{M})$ and surplus nitrate $(>5 \mu \mathrm{M})$ and phosphate $(>0.2 \mu \mathrm{M})$ concentrations (Egge 1993, 1998, Egge \& Jacobsen 1997). In addition, low temperature $\left(<10^{\circ} \mathrm{C}\right)$ and low incident irradiance ( $<20$ mol photons $\mathrm{m}^{-2} \mathrm{~d}^{-1}$ ) appear to favor $P$. pouchetii over diatoms (Ploug et al 1999a,b, Jacobsen 2000). However, in nature silicate availability is not a unique predictor of $P$. pouchetii versus diatom dominance, at least not in Norwegian fjords, coastal waters and the Barents Sea. A fundamental mechanistic understanding of all the factors that contribute towards $P$. pouchetii blooms thus remains elusive (Wassmann et al. 2000, Reigstad et al. 2002, Larsen et al. 2004, Schoemann et al. 2005, Nejstgaard et al. 2006).

As expected from previous studies, the addition of nitrate and phosphate without the addition of silicate resulted in an initial small diatom bloom which deteriorated when silicate declined below $1 \mu \mathrm{M}$, followed by a colonial bloom of Phaeocystis pouchetii (600 to $800 \mu \mathrm{g} \mathrm{C} \mathrm{l}^{-1}$ ). This pattern was consistent in both the 2002 and 2003 experiments. Thus, although there remains a considerable amount that is not known about the factors leading to the occurrence of colonial Phaeocystis spp. blooms in nature, blooms of $P$. pouchetii can be reliably simulated in Western Norwegian waters using nutrient manipulated mesocosm systems.

\section{Phaeocystis pouchetii colony formation}

The concentrations of solitary Phaeocystis pouchetii cells in the control and nutrient-amended mesocosms were essentially the same throughout both studies. Thus, the presence of natural concentrations of solitary $P$. pouchetii cells was by itself insufficient to explain the occurrence of colonial blooms. Wassmann et al. (2005) have recently emphasized that $P$. pouchetii 'events' do not have to occur as colony blooms: in north Norwegian fjords and elsewhere in the NE North Atlantic single cells may vastly outnumber co-occurring colony cells. In the present study, solitary cells increased marginally in abundance along with colonies 
in the nutrient-amended mesocosms, but the vast majority of total cells at the peak of the $P$. pouchetii bloom were contained within the colony matrix. In the absence of nutrient loading (control mesocosms), colonies were undetectable in 2002 and very low in 2003.

Adding cultured Phaeocystis pouchetii solitary cells, derived from the same waters and sufficient to nearly triple the natural concentration, did not result in differences in peak levels of colonies. Why? Several possible explanations exist: cultured cells did not survive, they were (selectively) eaten (further discussed in next subsection), or they could not form colonies in situ. An intriguing possibility derives from the colony formation incubation experiments. Initial concentrations of $P$. pouchetii solitary cells in the 3 colony initiation experiments in 2002 were 845, 750 and 657 cells ml ${ }^{-1}$, respectively. Comparing these to the production rates of new colonies (Fig. 12), it is apparent that roughly only $1 \%$ of the available solitary cells are required to account for the observed appearance of new colonies. Similar conclusions were derived from cultures of a Phaeocystis species (then called $P$. pouchetii, but most likely $P$. globosa) from the North Sea (Veldhuis \& Admiraal 1987). So, doubling or tripling the concentrations of solitary cells in the mesocosms at the time of filling might be inconsequential to subsequent colony abundance.

Mean net growth rates in numbers of colonies were 0.27 to $0.33 \mathrm{~d}^{-1}$ during the colony growth phase in all 4 NP-fertilized mesocosms (exponential phase, Table 1). These rates are not strictly comparable to those measured in the incubation experiments because the mesocosms include both formation of new colonies from solitary cells and division/budding of new colonies from old ones (Whipple et al. 2005), as well as potential loss factors e.g. zooplankton predation, lysis and sedimentation. There was no visual evidence in the incubation experiments of colony division/budding. However, given the similar concentrations of solitary cells in the mesocosms and in the experimental incubations, it is tempting to speculate that the formation rates of new colonies measured in the incubations may accurately represent the same processes in colonies in the mesocosms.

To our knowledge, it has previously not been possible to induce colony formation in traditional laboratory cultures of Phaeocystis pouchetii. Furthermore, many haptophytes do not reproduce conspicuous features such as toxicity even when cultured directly from toxic blooms in situ, and this may be a species-specific, or even strain-specific feature, with a complex and still largely unknown coupling to in situ growth conditions (e.g. Nielsen et al. 1990, Edvardsen \& Paasche 1998). However, here it was possible to induce colony forma- tion from single cells of $P$. pouchetii in the laboratory utilizing close to natural material and water from the mesocosms. This strongly supports the notion that traditional laboratory cultures may lack critical mechanisms or factors controlling growth and potential production of metabolites with key functions in natural systems. Thus, future studies should aim to unravel the controlling mechanisms, and results based on traditional laboratory cultures of Phaeocystis spp. and other haptophytes should be treated with caution when used for interpretation and modeling of complex natural systems.

\section{Trophic transfer of Phaeocystis pouchetii biomass}

Despite the large production of Phaeocystis pouchetii colonies, little of it appeared to be transferred to zooplankton biomass or to fuel virus production. Several components of the plankton communities did not differ saliently among mesocosms, i.e. concentrations of diatoms, bacteria and viruses, were similar between all 3 mesocosms each year, and relatively similar between years. Neither did the overall low biomass of ciliates and mesozooplankton indicate that they were significantly stimulated by the blooms of $P$. pouchetii in the fertilized mesocosms.

Only heterotrophic flagellates $>5 \mu \mathrm{m}$ and heterotrophic dinoflagellates were substantially greater in the NPF mesocosm in 2002. Perhaps the added Phaeocystis pouchetii solitary cells were consumed by microzooplankton? According to this notion, the initial addition of cultivated $P$. pouchetii solitary cells may have stimulated early development of several heterotrophic species, e.g. Gyrodinium spp., Rhizomonas sp. and oligotrich ciliates, that was only observed in the NPF mesocosm. In microzooplankton grazing experiments associated with these studies, heterotrophs were observed actively grazing on (also cultivated) DTAFlabeled P. pouchetii solitary cells (see Fu et al. 2003 for method and Anderson et al. 2002 for results). These results are also supported by $24 \mathrm{~h}$ dilution experiments using water from the NPF mesocosm, which showed daily community grazing rates of 33 to $95 \%$ of the standing stock of $<8 \mu \mathrm{m}$ cells early in the study (11 to 15 March), but only $4 \%$ later on 19 to 20 March (Nejstgaard et al. unpubl. data). These observations support the hypothesis that the early seeding of cultured $P$. pouchetii solitary cells did not lead to more colonies later because only a small fraction of them formed colonies and an unknown (but perhaps large) fraction was consumed by protist grazers.

The mesozooplankton biomass remained about 1 order of magnitude lower than previously recorded in comparable mesocosm experiments at this site (e.g. 
Levasseur et al. 1996, Nejstgaard et al. 2001, Svensen et al. 2002). This observation was surprising given the development of strong differences in prey availability between the treatments. However, this supports the notion that Phaeocystis pouchetii may be a suboptimal food that does not support strong zooplankton production (Cotonnec et al. 2001, Tang et al. 2001, Klein Breteler \& Koski 2003, but see Weisse et al. 1994 and Turner et al. 2002 for exceptions). The lack of trophic transfer to the zooplankton could be due to one, or several, of the defense mechanisms against predation suggested for Phaeocystis spp. The defense mechanisms include (1) formation of colonies to escape vigorous feeding by microzooplankton, as showed for cultured P. globosa (Jakobsen \& Tang 2002, Tang 2003, Long 2005), (2) reduced palatability depending on the physiological state, exudates, species or even type of single cell (Estep et al. 1990, Dutz et al. 2005, Long 2005, Dutz \& Koski 2006, Nejsgaard et al. 2006), (3) other factors (see review by Weisse et al. 1994).

On the other hand, due to the low abundance of mesozooplankton, they are not likely to have produced any substantial grazing pressure on the nano- or microplankton in any of the mesocosms, as was confirmed in the mesozooplankton feeding experiments coupled to the dilution experiments on 11, 15 and 19 March (Nejstgaard et al. unpubl. data). Thus, mesozooplankton could not be responsible for any of the differences in nano- and microplankton development between the mesocosms, since the composition and biomass of the mesozooplankton was almost identical between all 3 mesocosms in each year, and similarly low in both years. Moreover, even a 10-fold increase in mesozooplankton concentrations greater than those recorded here, would still show (at best) a small direct grazing pressure on the largest microzooplankton, such as ciliates larger than 20 to $30 \mu \mathrm{m}$ (Nejstgaard et al. 1997). In addition, a large fraction of the mesozooplankton was made up of meroplankton, including barnacle larvae, which are generally less efficient grazers than copepods of the same size (Hansen et al. 1997, Desai \& Anil 2004). Thus, the P. pouchetii blooms did not seem to be significantly grazed or support any significant production of mesozooplankton.

\section{Bacteria and viruses}

We did not observe strong variability in bacterial abundances between the fertilized and non-fertilized mesocosms, as often observed elsewhere (Cottingham et al. 1997, Joint et al. 2002, Havskum et al. 2003). One interpretation is that bacterial populations were not limited by inorganic nutrients and that increasing bacterial abundance was either the result of growth stimu- lated by increased primary production (via release of labile DOC) or a decrease in bacterial grazing. One caveat with the former explanation is that the rate of increase in bacteria cells was similar in all 3 mesocosms, even though productivity had to be much greater in the nutrient-amended mesocosms. In other studies associated with these experiments, bacteria productivity and biomass increased in response to fertilization, although bacterial abundance did not vary among treatments (Frischer et al. 2005 and unpubl. data) Nevertheless, bacterial growth estimated from total cell abundance exceeded combined bacterial mortality, independent of external nutrient loading, such that the net increases in abundance were similar in the 3 mesocosms. In modeled systems, Thingstad and colleagues have thoroughly evaluated the balance of these factors (Thingstad \& Lignell 1997, Thingstad et al. 1999). Phaeocystis spp. specific viruses have previously been shown to terminate blooms of $P$. pouchetii in mesocosms at this location (Jacobsen 2000), and are suspected to terminate such blooms in the nearby Raunefjord (Larsen et al. 2004). Although there was evidence for the presence of Phaeocystis spp.-specific viruses during these studies (Jacobsen et al. 2005 and unpubl. data), the co-variation between bacterial abundance and virus abundance observed in these studies suggest that virus communities were dominated by bacteriophages and that viral lysis did not contribute to re-proportioning biomass associated with $P$. pouchetii during the course of these experiments.

\section{Conclusions and suggestions for future research towards understanding complexity of marine planktonic systems}

The preceding discussion outlines several explanations for the observed patterns and highlights where observations revealed discrepancies with theory. Several of these are under investigation in similar mesocosm or more controlled laboratory studies including: (1) What other factors influence the transition from solitary cell to colony cell phase of the Phaeocystis pouchetii life cycle? Some possibilities include the role of sediments and potential stimulation by the cell surfaces of co-occurring diatoms. (2) What is the role of emigration of cells out of colonies during the demise of colony blooms. In this study, microscopy confirmed that, on the last sample days, cells within colonies had become motile and were initiating exodus, as observed in Phaeocystis spp. elsewhere (Parke et al. 1971, Verity et al. 1988b). (3) Does bacterial community composition change in response to Phaeocystis spp.? Perhaps the lack of differences in treatment effects on bacteria abundance masked activity and diversity responses. 
(4) What is the role of viral lysis, in colony bloom dynamics and termination? The virus data in Figs. 5 \& 6 probably reflects bacteria-specific viruses because of the similar temporal patterns of bacteria and viruses, and the numerical dominance of bacterial hosts compared to potential algal hosts. Host/virus systems are known for P. pouchetii (Jacobsen et al. 1996, Bratbak et al. 1998a,b, Brussaard et al. 1999), but the viruses do not seem to affect the colony life cycle phase. Incubation experiments during the present study showed no evidence of viral lysis of colonies even though $P$. pouchetii-specific viruses were present in the mesocosms (Jacobsen et al. unpubl. data). (5) Does chemical communication between life cycle stages and among life cycles stages and zooplankton influence phytoplankton species succession? (6) What are the quantitative roles of various proto- and mesozooplankton in these processes?

Complexity theory postulates that inherent in complex systems are self-organizational tendencies that structure complex systems. Entire ecosystems change in conjunction with shifts in the life cycle and dominance of Phaeocystis spp., and there are examples of direct biochemical communication among trophic levels in response to Phaeocystis spp. dynamics. From the perspective of complexity theory, the biology of Phaeocystis spp. involving a life-history strategy that includes small ( 3 to $9 \mu \mathrm{m}$ ) single cells and large (up to $\mathrm{mm}$ ) sized colonies may be considered to represent such a self-organization property of high latitude planktonic ecosystems. The complexity apparent in the magnitude and nature of all of these interactions is large, and it remains difficult to resolve clear causality in diverse systems, even under the physically conscribed conditions created in these studies. The answers to the specific question raised here concerning the trophic effect of stimulating a colonial bloom of $P$. pouchetii by fertilization with nitrate and silicate, remain ambiguous. Certainly, the fundamental prediction that the addition of $\mathrm{N}$ and $\mathrm{P}$ to these systems would lead to significantly higher phytoplankton biomass and a colonial P. pouchetii bloom was supported. Furthermore, the $P$. pouchetii bloom appeared to have structured the planktonic system by limiting secondary production to levels equivalent to non-bloom conditions. However, the hypothesis that this bloom would result in a restructuring of the planktonic community was not supported. Except for the obvious differences in the abundance of $P$. pouchetii, other system components (viruses, bacteria, nano-, microplankton and mesozooplankton) appeared to be essentially unaffected by this system alternation. Apparently, P. pouchetii is capable of limiting system complexity by sequestering nutrients and energy into forms not easily accessible to planktonic grazing and regenerating communities that comprise northern latitude marine systems.
Acknowledgements. A mesocosm facility does not run by itself, nor can all of routine sampling and analyses be conducted by only a few limited personnel. We thank Thomas Sørlie, Agnes Aadnesen and Halfdan Gjertsen for their friendly and courteous service at the Espegrend field station while these studies were underway, and for their tireless efforts to find replacements, fix broken equipment, and get critical supplies on very short notice. Several technical staff helped with sample collection and processing including Mette Hordnes, Evy Foss Skjoldal and Solveigh Torkildsen. We thank the University of Bergen for use of the facility, and the laboratories of Gunnar Bratbak and Frede Thingstad for use of equipment, logistical support, and for sample analysis. J. C. Nejstgaard was supported by the Norwegian Research Council (152714/120). This study was also funded by the US National Science Foundation Office of Polar Programs grant (OPP-00-83381) and the US Department of Energy Biotechnology Investigations - Ocean Margins Program (FG02-98EF 62531). The figures were prepared by Ms. Anna Boyette.

\section{LITERATURE CITED}

Anderson JT, Verity PG, Kohlberg K (2002) Application of fluorescent stains to determine trophic role of Phaeocystis pouchetii (Prymnesiophyceae); American Society of Limnology and Oceanography, Waco, TX, p 17

Båmstedt U (1986) Chemical composition and energy content. In: Corner EDS, O'Hara SCM (eds) The biological chemistry of marine copepods. Oxford University Press, Oxford, p 1-58

Båmstedt U, Håkanson JL, Brenner-Larsen J, Bjørnsen PK, Geertz-Hansen O, Tiselius P (1990) Copepod nutritional condition and pelagic production during autumn in Kosterfjorden, western Sweden. Mar Biol 104:197-208

Blom $G$, Otterå $H$, Svåsand $T$, Kristiansen TS, Serigstad B (1989) The relationship between feeding conditions and production of cod fry (Gadus morhua) in a semi-enclosed marine ecosystem in western Norway, illustrated by use of a consumption model. ICES Mar Sci Symp 192:176-189

Boalch GT (1987) Recent blooms in the western English Channel. Rapp PV Réun Cons Int Explor Mer 187:94-97

Bratbak G, Jacobsen A, Heldal M (1998a) Viral lysis of Phaeocystis pouchetii and bacterial secondary production. Aquat Microb Ecol 16:11-16

Bratbak G, Jacobsen A, Heldal M, Nagasaki K, Thingstad F (1998b) Virus production in Phaeocystis pouchetii and its relation to host cell growth and nutrition. Aquat Microb Ecol 16:1-9

Brussaard CPD, Thyrhaug R, Marie D, Bratbak G (1999) Flow cytometric analyses of viral infection in two marine phytoplankton species, Micromonas pusilla (Prasinophyceae) and Phaeocystis pouchetii (Prymnesiophyceae). J Phycol 35:941-948

Chen YQ, Wang N, Zhang P, Zhou H, Qu LH (2002) Molecular evidence identifies bloom-forming Phaeocystis (Prymnesiophyta) from coastal waters of southeast China as Phaeocystis globosa. Biochem Syst Ecol 30:15-22

Conover RJ, Lalli CM (1972) Feeding and growth in Clione limacina (Phipps), a pteropod mollusc. J Exp Mar Biol Ecol 9:279-302

Cotonnec G, Brunet C, Sautour B, Thoumelin G (2001) Nutritive value and selection of food particles by copepods during a spring bloom of Phaeocystis sp. in the English Channel, as determined by pigment and fatty acid analyses. J Plankton Res 23:693-703

Cottingham KL, Knight SE, Carpenter SR, Cole JJ, Pace ML, Wagner AE (1997) Response of phytoplankton and bacte- 
ria to nutrients and zooplankton-a mesocosm experiment. J Plankton Res 19:995-1010

Daan R (1986) Food intake and growth of Sarsia tubulosa (Sars, 1835), with quantitative estimates of predation on copepod populations. Neth J Sea Res 20:67-74

Desai DV, Anil AC (2004) The impact of food type, temperature and starvation on larval development of Balanus amphitrite Darwin (Cirripedia: Thoracica). J Exp Mar Biol Ecol 306:113-137

Duarte CM, Gasol JM, Vaque D (1997) Role of experimental approaches in marine microbial ecology. Aquat Microb Ecol 13:101-111

Dutz J, Koski M (2006) Low grazing vulnerability in flagellated, solitary cells of the prymnesiophyte Phaeocystis globosa. Limnol Oceanogr 51:1230-1238

Dutz J, Klein Breteler WCM, Kramer G (2005) Inhibition of copepod feeding by exudates and transparent exopolymer particles (TEP) derived from a Phaeocystis globosa dominated phytoplankton community. Harmful Algae 4:929

Edvardsen B, Paasche E (1998) Bloom dynamics and physiology of Prymnesium and Chrysochromulina. In: Anderson DM, Cembella AD, Hallegraef GM (eds) The physiological ecology of harmful algal blooms. Springer-Verlag, Heidelberg, p 193-208

Egge JK (1993) Nutrient control of phytoplankton growth: effects of macronutrient composition (N, P, Si) on species succession. PhD thesis, University of Bergen

Egge JK (1998) Are diatoms poor competitors at low phosphate concentrations? J Mar Syst 16:191-198

Egge JK, Aksnes DL (1992) Silicate as regulating nutrient in phytoplankton competition. Mar Ecol Prog Ser 83:281-289

Egge JK, Jacobsen A (1997) Influence of silicate on particulate carbon production in phytoplankton. Mar Ecol Prog Ser 147:219-230

Eilertsen HC, Schei B, Taasen JP (1981) Investigations on the plankton community of Balsfjorden, northern Norway: The phytoplankton 1976-1978: abundance, species composition and succession. Sarsia 66:129-142

Erga SR (1989) Ecological studies on the phytoplankton of Boknafjorden, Western Norway. 1. The effect of water exchange processes and environmental factors on temporal and vertical variability of biomass. Sarsia 74:161-176

Erga SR, Heimdal BR (1984) Ecological studies on the phytoplankton of Korsfjorden, western Norway. The dynamics of a spring bloom seen in relation to hydrographical conditions and light regime. J Plankton Res 6:67-90

Escaravage V, Peperzak L, Prins TC, Peeters JCH, Joordens JCA (1995) The development of a Phaeocystis bloom in a mesocosm experiment in relation to nutrients, irradiance and coexisting algae. Ophelia 42:55-74

Estep KW, Nejstgaard JC, Skjoldal HR, Rey F (1990) Predation by copepods upon natural populations of Phaeocystis pouchetii as a function of the physiological state of the prey. Mar Ecol Prog Ser 67:235-249

Falkenhaug T (1991) Prey composition and feeding rate of Sagitta elegans var. arctica (Chaetognatha) in the Barents Sea in early summer. Polar Res 10:487-506

Fernandez E, Serret P, de Madariaga I, Harbour DS, Davies AG (1992) Photosynthetic carbon metabolism and biochemical composition of spring phytoplankton assemblages enclosed in mesocosms: the diatom-Phaeocystis species succession. Mar Ecol Prog Ser 90:89-102

Frischer ME, Baylor VD, Walters TL, Danforth JD, Verity PG (2005) The rich get richer: individual cell and community bacterial response to an induced bloom of Phaeocystis pouchetii. American Society of Limnologgy and Oceanography, Waco, TX, p 53
Fu Y, O'Kelly C, Sieracki M, Distel DL (2003) Protistan grazing analysis by flow cytometry using prey labeled by in vivo expression of fluorescent proteins. Appl Environ Microbiol 69:6848-6855

Gorsky G, Fenaux R (1998) The role of Appendicularia in marine food webs. In: Bone Q (ed) The biology of pelagic tunicates. Oxford University Press, Oxford, p 161-169

Guillard RRL (1975) Culture of phytoplankton for feeding marine invertebrates. In: Smith WL, Chanley MH (eds) Culture of marine invertebrate animals. Plenum Press, New York, p 29-60

Haas LW (1982) Improved epifluorescence microscopy for observing planktonic micro-organisms. Ann Inst Océanogr 58:261-266

Hagebø M, Rey F (1984) Lagring av sjøvann til analyse av næringssalter. Fisken Havet 4:12 (English summary)

Hamm CE, Simson DA, Merkel R, Smetacek V (1999) Colonies of Phaeocystis globosa are protected by a thin but tough skin. Mar Ecol Prog Ser 187:101-111

Hansen PJ, Bjørnsen PK, Hansen BW (1997) Zooplankton grazing and growth: scaling within the $2-2,000-\mu \mathrm{m}$ body size range. Limnol Oceanogr 42:687-704

Havskum H, Thingstad TF, Scharek R, Peters F and 8 others (2003) Silicate and labile DOC interfere in structuring the microbial food web via algal-bacterial competition for mineral nutrients: results of a mesocosm experiment. Limnol Oceanogr 48:129-140

Heimdal BR (1974) Composition and abundance of phytoplankton in the Ullsfjord area, North Norway. Astarte 7: $17-42$

Holms RM, Aminot A, Kèrouel R, Hooker BA, Peterson BJ (1999) A simple and precise method for measuring ammonium in marine and freshwater ecosystems. Can J Fish Aquat Sci 56:1801-1808

Howard-Jones MH, Frischer ME, Verity PG (2001) Determining the physiological status of individual bacteria cells. In: Paul JH (ed) Methods in microbiology, Vol 30: Marine microbiology. Academic Press, London, p 175-206

Jacobsen A (2000) New aspects of bloom dynamics of Phaeocystis pouchetii (Haptophyta) in Norwegian waters. $\mathrm{PhD}$ thesis, University of Bergen

Jacobsen A, Egge JK, Heimdal BR (1995) Effects of increased concentration of nitrate and phosphate during a spring bloom experiment in mesocosm. J Exp Mar Biol Ecol 187: $239-251$

Jacobsen A, Bratbak G, Heldal M (1996) Isolation and characterization of a virus infecting Phaeocystis pouchetii (Prymnesiophyceae). J Phycol 32:923-927

Jacobsen A, Martínez-Martínez J, Verity P, Frischer ME, Sandaa RA, Larsen A (2005) Are colonies or colonial cells of Phaeocystis pouchetii (Prymnesiophyceae) suseptible to virus infection? American Society of Limnology and Oceanography, Waco, TX, p 73

Jakobsen HH, Tang KW (2002) Effects of protozoan grazing on colony formation in Phaeocystis globosa (Prymnesiophyceae) and the potential costs and benefits. Aquat Microb Ecol 27:261-273

Karlson K, Båmstedt U (1994) Planktivorous predation on copepods. Evaluation of mandible remains in predator guts as a quantitative estimate of predation. Mar Ecol Prog Ser 108:79-89

Klein Breteler WCM, Koski M (2003) Development and grazing of Temora longicornis (Copepoda, Calanoida) nauplii during nutrient limited Phaeocystis globosa blooms in mesocosms. Hydrobiologia 491:185-192

Kornmann VP (1955) Beobachtungen an Phaeocystis-Kulturen. Helgoländer Wiss Meeresunters 5:218-233 
Joint I, Henriksen P, Fonnes GA, Bourne D, Thingstad TF, Riemann B (2002) Competition for inorganic nutrients between phytoplankton and bacterioplankton in nutrient manipulated mesocosms. Aquat Microb Ecol 29:145-159

Lancelot C, Keller MD, Rousseau V, Smith WO Jr, Mathot S (1998) Autecology of the marine haptophyte Phaeocystis sp. NATO ASI Ser Ser G Ecol Sci 4:209-224

Larsen A, Flaten GA Fonnes, Sandaa RA and 5 others (2004) Spring phytoplankton bloom dynamics in Norwegian coastal waters: microbial community succession and diversity. Limnol Oceanogr 49:180-190

Levasseur M, Michaud S, Egge JK, Cantin G and 6 others (1996) Production of DMSP and DMS during a mesocosm study of an Emiliania huxleyi bloom: influence of bacteria and Calanus finmarchicus grazing. Mar Biol 126:609-618

Long J (2005) Plasticity in consumer-prey interactions in the sea: chemical signaling, learned aversion, and ecological consequences. PhD thesis. Georgia Institute of Technology, Atlanta, GA

Marie D, Brussaard CPD, Thyrhaug R, Bratbak G, Vaulot D (1999a) Enumeration of marine viruses in culture and natural samples by flow cytometry. Appl Environ Microbiol 65:45-52

Marie D, Simon N, Brussaard CPD, Partensky F, Vaulot D (1999b) Flow cytometric analysis of phytoplankton, bacteria and viruses. Cur Protocols Cytom, John Wiley \& Sons, 11.11.1-11.11.15

Menden-Deuer S, Lessard EJ (2000) Carbon to volume relationships for dinoflagellates, diatoms, and other protist plankton. Limnol Oceanogr 45:569-579

Nejstgaard JC, Gismervik I, Solberg PT (1997) Feeding and reproduction by Calanus finmarchicus, and microzooplankton grazing during mesocosm blooms of diatoms and the coccolithophore Emiliania huxleyi. Mar Ecol Prog Ser 147:197-217

Nejstgaard JC, Hygum BH, Naustvoll LJ, Båmstedt U (2001) Zooplankton growth, diet and reproductive success compared in simultaneous diatom- and flagellate-microzooplankton-dominated plankton blooms. Mar Ecol Prog Ser 221:77-91

Nejstgaard JC, Tang KW, Steinke M, Dutz J, Koski M, Antajan E, Long JD (2006) Zooplankton grazing on Phaeocystis: a quantitative review and future challenges. Biogeochemistry (in press)

Nielsen TG, Kiørboe T, Bjørnsen PK (1990) Effects of a Chrysochromulina polylepis subsurface bloom on the planktonic community. Mar Ecol Prog Ser 62:1-2

Parke M, Green JC, Manton I (1971) Observations on the fine structure of zooids of the genus Phaeocystis (Haptophyceae). J Mar Biol Assoc UK 51:927-941

Parsons TR, Maita Y, Lalli CM (1984) A manual of chemical and biological methods for seawater analysis. Pergamon Press, Oxford

Peperzak LM, Colijn F, Gieskes WWC, Peeters JCH (1998) Development of the diatom-Phaeocystis spring bloom in the Dutch coastal zone of the North Sea: the silicon depletion versus the daily irradiance threshold hypothesis. J Plankton Res 20:517

Peperzak L, Colijn F, Vrieling EG, Gieskes WWC, Peeters $\mathrm{JCH}$ (2000) Observations of flagellates in colonies of Phaeocystis globosa (Prymnesiophyceae); a hypothesis for their position in the life cycle. J Plankton Res 22: 2181-2203

Ploug H, Stolte W, Epping EGH, Jørgensen BB (1999a) Diffusive boundary layers, photosynthesis, and respiration of the colony-forming plankton algae, Phaeocystis sp. Limnol Oceanogr 44:1949-1958
Ploug H, Stolte W, Jørgensen BB (1999b) Diffusive boundary layers of the colony-forming plankton alga Phaeocystis sp._-implications for nutrient uptake and cellular growth. Limnol Oceanogr 44:1959-1967

Porter KG, Feig YS (1980) The use of DAPI for identifying and counting aquatic microflora. Limnol Oceanogr 25: 943-948

Reigstad M, Wassmann P, Wexels Riser C, Øygarden S, Rey F (2002) Variation in hydrography, nutrients, and chlorophyll $a$ in the marginal ice zone and the central Barents Sea. J Mar Syst 38:9-29

Riegman R, van Boekel W (1996) The ecophysiology of Phaeocystis globosa: a review. J Sea Res 35:235-242

Rousseau V, Vaulot D, Casotti R, Cariou V, Lenz J, Gunkel J, Baumann M (1994) The life cycle of Phaeocystis (Prymnesiophyceae): evidence and hypotheses. J Mar Syst 5:23-39

Schoemann V, Becquevort S, Stefels J, Rousseau V, Lancelot C (2005) Phaeocystis blooms in the global ocean and their controlling mechanisms: a review. J Sea Res 53:43

Smaal AC, Twisk F (1997) Filtration and absorption of Phaeocystis cf. globosa by the mussel Mytilus edulis L. J Exp Mar Biol Ecol 209:33-46

Svensen C, Nejstgaard JC, Egge JK, Wassmann P (2002) Pulsing versus constant supply of nutrients $(\mathrm{N}, \mathrm{P}$ and $\mathrm{Si})$ : effect on phytoplankton community, mesozooplankton grazing and vertical flux of biogenic matter. Sci Mar 66:189-203

Tang KW (2003) Grazing and colony size development in Phaeocystis globosa (Prymnesiophyceae): the role of a chemical signal. J Plankton Res 25:831-842

Tang KW, Jakobsen HH, Visser AW (2001) Phaeocystis globosa (Prymnesiophyceae) and the planktonic food web: feeding, growth, and trophic interactions among grazers. Limnol Oceanogr 46:1860-1870

Theilacker GH, Kimball AS (1984) Comparative quality of rotifers and copepods as foods for larval fishes. Calif Coop Ocean Fish Investig Rep 25:80-86

Thingstad TF, Lignell R (1997) Theoretical models for the control of bacterial growth rate, abundance, diversity and carbon demand. Aquat Microb Ecol 13:19-27

Thingstad TF, Havskum H, Kaas H, Lefevre D, Nielsen TG, Riemann B, Williams PJLeB (1999) Bacteria-protist interactions and organic matter degradation under P-limited conditions: comparison between a mesocosm experiment and a simple model. Limnol Oceanogr 44:62-79

Turner JT, Ianora A, Esposito F, Carotenuto Y, Miralto A (2002) Zooplankton feeding ecology: does a diet of Phaeocystis support good copepod grazing, survival, egg production and egg hatching success? J Plankton Res 24: 1185-1195

Valderrama JC (1995) Methods of nutrient analysis. In: Hallegraeff GM, Anderson DM, Cembella AD (eds) Manual on harmful marine microalgae. IOC Manuals and Guides No. 33. UNESCO, Paris, p 251-268

Valero M, Richerd S, Perrot V, Destombe C (1992) Evolution of alteration of haploid and diploid phases in life cycles. Trends Ecol Evol 7:25-29

Veldhuis MJW, Admiraal W (1987) Influence of phosphate depletion on the growth and colony formation of Phaeocystis pouchetii. Mar Biol 95:47-54

Verity PG (2000) Grazing experiments and model simulations of the role of zooplankton in Phaeocystis food webs. J Sea Res 43:317-343

Verity PG, Medlin LK (2003) Observations on colony formation by the cosmopolitan phytoplankton genus Phaeocystis. J Mar Syst 43:153-164

Verity PG, Villareal TA, Smayda TJ (1988a) Ecological investigations of blooms of colonial Phaeocystis pouchetii. 
I. Abundance, biochemical composition, and metabolic rates. J Plankton Res 10:219-248

Verity PG, Villareal TA, Smayda TJ (1988b) Ecological investigations of blooms of colonial Phaeocystis pouchetii. II. The role of life cycle phenomena in bloom termination. J Plankton Res 10:749-766

Wassmann P, Vernet M, Mitchell BG, Rey F (1990) Mass sedimentation of Phaeocystis pouchetii in the Barents Sea. Mar Ecol Prog Ser 66:183-195

Wassmann P, Reigstad M, Øygarden S, Rey F (2000) Seasonal variation in hydrography, nutrients, and suspended biomass in a subarctic fjord: applying hydrographic features and biological markers to trace water masses and circulation significant for phytoplankton production Sarsia 85:237-249

Wassmann P, Ratkova T, Reigstad M (2005) The contribution of single and colonial cells of Phaeocystis pouchetii to spring and summer blooms in the north-eastern North Atlantic. Harmful Algae 4:823-840

Weisse T, Tande K, Verity P, Hansen F, Gieskes W (1994) The

Editorial responsibility: Otto Kinne (Editor-in-Chief),

Oldendorf/Luhe, Germany trophic significance of Phaeocystis blooms. J Mar Syst 5: $67-79$

Whipple SJ, Patten BC, Verity PG (2005) Colony growth and evidence for colony multiplication in Phaeocystis pouchetii (Prymnesiophyceae) isolated from mesocosm blooms. J Plankton Res 27:495-501

Whyte JNC, Bourne N, Hodgson CA (1987) Assessment of biochemical composition and energy reserves in larvae of the scallop Patinopecten yessoensis. J Exp Mar Biol Ecol 113:113-124

Widdows J (1991) Physiological ecology of mussel larvae. Aquaculture 94:2-3

Williams PJ LeB, Egge JK (1998) The management and behaviour of the mesocosms. Estuar Coast Shelf Sci 46:3-14

Williams SC, Hong Y, Danavall DCA, Howard-Jones MH, Gibson D, Frischer ME, Verity PG (1998) Distinguishing between living and nonliving bacteria: evaluation of a combined molecular probe and vital staining procedure. J Microbiol Methods 32:225-236

Submitted: December 6, 2004; Accepted: January 30, 2006 Proofs received from author(s): August 21, 2006 